University of Louisville

ThinkIR: The University of Louisville's Institutional Repository

Electronic Theses and Dissertations

1933

\title{
The conference of Algeciras 1906.
}

Marjorie Lucille Rogers

University of Louisville

Follow this and additional works at: https://ir.library.louisville.edu/etd

Part of the African History Commons, and the Diplomatic History Commons

\section{Recommended Citation}

Rogers, Marjorie Lucille, "The conference of Algeciras 1906." (1933). Electronic Theses and Dissertations. Paper 1884.

https://doi.org/10.18297/etd/1884

This Master's Thesis is brought to you for free and open access by ThinkIR: The University of Louisville's Institutional Repository. It has been accepted for inclusion in Electronic Theses and Dissertations by an authorized administrator of ThinkIR: The University of Louisville's Institutional Repository. This title appears here courtesy of the author, who has retained all other copyrights. For more information, please contact thinkir@louisville.edu. 


\title{
ONIVERSITY OF LOUISVILIE
}

THE CONFERENCE OF ALAECIRAS 1906

\author{
A Dissertation \\ Submitted to tho Faculty \\ of the Graduate school of the University of Ious aville \\ In Partial Fulfillwent of the \\ Requirements for the Degree \\ of Master of Arts
}

Department of History

by

Marjorie Inc1lle Rogers

1933 
THE CONFERENCE OF ALAFCIRAS, 1906 
- PREFACE *- 
PREPACE.

The Algeciras Conferenoe can not be thought of as a single isolated ovent or as the product of a moment. It is Iinked to the facts that both precede and follow 1t. There was never a fact in history that did not have other facts responsible for it or was not itsolf responsible for mang coming after 1t, and if the writer shall se日m to set a rather arbitrary beginning and endIng for this account of the Conference, let the reader remomber she does so for conventence only, and that the present can no more be cut from the past of which it is a product than the future can escape being shaped by the present. The Conference of Algeolras, then, is morely an incident, at once a cause and a result, in the long story of Frenco-German friction, of which the origin 18 obscure and the end jet invisible. 
-4 M A P *- 


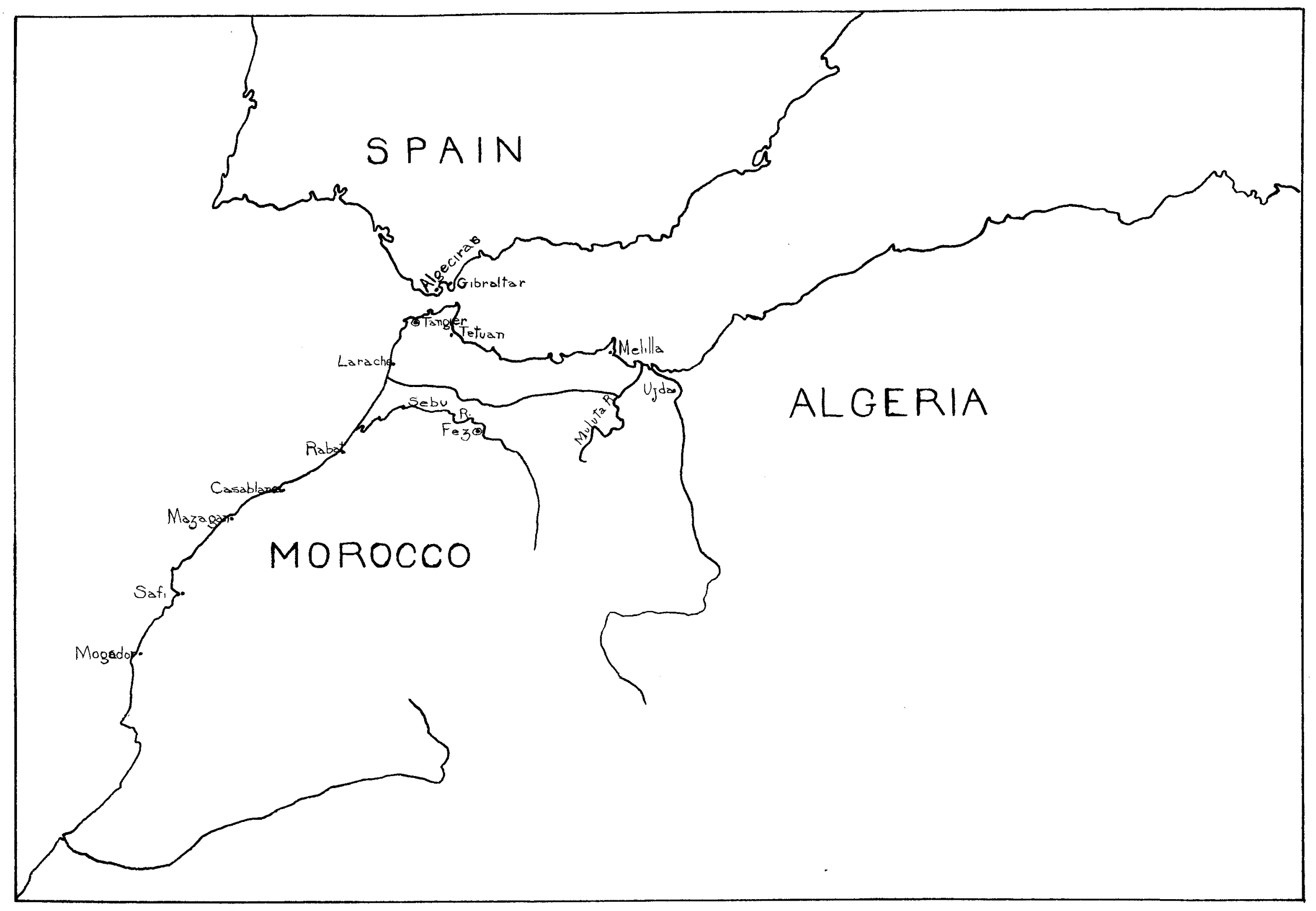


TABLE OF CONTENTS 
Preface

Map

Chapter

Page

I International Friction in Morocco

II The Fay Out: An Intermat1onal Conference 26

III The Problem of the State Bank 50

Iv The Problem of the Pollco 60

V Conclusion $\quad 80$ 
Chapter I

INTERNATIOYAL FRICTION IN NOROCCO 
THE CONFERENCE OF ALOECIRAS

Chapter I

International Friction in Morocco

In the opening years of the trentieth century there came under the control of a Eropean state the last of the backward nations, Morocco. For conturies during which more or less regular diplomatic and commerclal relations were carried on w1th European powers, Morocco resisted western elvilization. That she had been able to hold out longer than countries of the same sort as herself, espocially against control by a western nation, was due partiy to the perlod of relatively strong mile which prevalled in the state between 1813 and 1900 , a perlod which began before the era of imperlallam was thoroughly started. The country had been ably governed by the sultan, Mula1-ol-Hassan, unt1l his death in 1894 when the power fell into the hands of the grand vizler, Ba-Ahmod. The latter's equaliy effective rule came to an end when ho died in 1900.

The new Sultan was mere jouth, and though intelIlgent and attractive, was 1ll-equipped to wield his athority. Unlike the great mass of his people, Abdel-Az1z was inordinately fond of many of the products of European civilization, such as bicycles, motor-cars, photography and fireworks. At length, the young man's 
extravagance emptied the Noroccan treasuiry. In an attempt to save the situation, the government increased the taxes. The ner taxes not only were extremely heav bat a.so wore in violation of the Koran. Under these circumstances, the natives, who thoroughly resented the1r sultan's conduct, revolted. The political and religious ties of the people began to glve way. By 1903 the Moroccan capital, Fez, was throatened by the rebels, and tho sultan's authority extended to only a few towns. He had no mones, therefore no army. One writer has compared Morocco to a foudal state of a type to be found in Europo about tho jear 1000.1. Inde日d, it was littlo else; the Sultan was Sultan in namo only. Eren the geography of the country m111tated against national unity. Thus, Yorocco was a lovely moreel ready to be devoured by a hungry lediterranean nation seeking sources of food supplies, raw mater1als, markets and strategloal1y located land. Furthermore, an excelient excuse for Intervention in Moroccan affairs existed. Tho disorder in the country, which natura11y endangered the $11 \mathrm{ves}$ and property of forelgners, made protection of them an urgent intemational question.

Aside from the fact of a relatively strong internal government under Mule1-EI-Hassan, it is to be rondered why Morocco was not al ready taken in tow by one of the great Western powers. The reason is $81 \mathrm{mple}$ enough. The nations which chiefly coveted Morocco were those having

\footnotetext{
1.B, B. Sohmitt, Fngland and Germany 1740-1914,228f
} 
Westerm Mediterranean interest8, 1.0., Oreat Britain, Cormany, France, Spain and Italy. Morocco was contiguous to the French and Spanish possessions in Northern Africa and was situated near to spain on the straits of abraltar. She was also on the route to South Africa. out of the fact of her locetion, then, grew a conflict or strategic interesta between the powers. Though each of the western nations concerned longed to gain the upper hand in Morocco, each suspected that the others would take advantage of their position if similarly situated. Eonce, the powers desired to maintain a state of affairs which should keep every foreign nation in Morocco within well defined Iimtts. To achleve this end had been the actual purpose of a Conference hold at Madrid in 1880. The Conference, in settling number of comerciel problems, had concluded that every nation represented at Madrid should have most-favored-nation treatmont in Morocco. The Sulten's Independence and sovereignty were, of course, guaranteod. It might be added thet up to 1903, at least, fore1gn trade with Morocco was not largo. But, as it has been aptly put, "Increasing Insecurity of forelgners and the Sultan's need for losns foreshadowed the end of Moroocen Independence." 1 .

There was, however, one nation that had been Intensely alert to conditions in Morocco, and was turn-

1:E.N.Anderson, The First Moroccan Cr1s1s, 19041806,4 . Hereaf ter this work will be cited as Anderson, Moroccan Cris1s. 
Ing them to advantage at every opportunity. Like hor sister atatä, France had declered herself in favor of the status quo in Morocco, but, 11ke them also, not through any special respect which she entertalned toward the North African country, for she had no desire to see Horocco reform herself. France's main Idea was to prevent any other Porer from gaining too much influence. The foregoing policy was pursued through the 1890's, after which came a visiblo change. A combination of factors wight be sald to have been responsible. The international situation was especially favorable to a change of policy. Three of the Porerg interested in yediterranean affalrs were laden wth troubles of their own: Great Britain occupied with the Boer War; Italy defeated by Abysinis in 1896, and spain by the Onited states in 1898. The internal disintegration of Horocco has already been referred to above. But even a favorable international situation might not have been oufficient to induce an unwililng nation to embark upon an Imperialistic program likely to prove a rough sea. There were other forces at work.

The French people had been carefully prepared for the day when France should be able to extend her African poseessions to Include Morocco. Development of an att1tude favorable to colonial aqquisition, particulariy in Africa, was largely the work of an organization having a small but distinguished mombership -- the Comite de 
l'Afrigue francaise. Because of the high position held by many of the mombers in state affalrs, the Comite was in a position to exercise considerable influence upon the French govermment as well as on the nation. The Comité went so far as to formulate a policy which it desired to see the government pursue, and which the latter did come to follow to a large extent. Th1s polloy mey be sumed up, in general, as follows:

(1) The French government was to make agreements with Interested stetes respecting Morocco:

(2) The overeignty of the sultan and the integrity of h1s land to be assured;

(3) The freedom of the stracte to be adequately guaranteod;

(4) Satisfaction for the logitima interests of the powers, considered chleply economic, through full comercial liberty;

(5) Recognition of Spain's territorial claims;

(6) "Pacific penetration" to be the method used in wiming Morocco by means of control over the Sultan, who was the sole source of religlous and political authorityd Pacific penetration would gain the good will of the French people and would prevent other powers from taking offense.

The Comite is arguments in behalf of 1 ts pollcy ranged from the reasonable to the ridiculous, but 1ts campal on was highly successful and nearly the whole nation was 
converted to the Morocco policy.

All that was then lacking to make a change in the government's policy both positive and effective was a leader fired with the ldeas of the Comite and intelligent enough to make thom a reality. Such a one was M. Theophile Delcasse, who became Minister of Foreigin Affairs in 1898. Delcassé was a strange man, to say the lesst, a highly uncomunicative person who immediately assumed complete independence in performing the functions of $\mathrm{hls}$ office. Taking advantage of Parliament's preoccupation with internal affairs, he carried out his policy of maintaining and developing French interesto. Ho almed at Increasing French prestige and rounding out her possessions in Africa. Control of Morocco would be source of defense to France, because of 1 ts proximity to France's other African possessions, as seen by a glance at the map. To sum up the situation, we see that all the conditions were favorable to on agressive policy on the part of France in Morocco. The powers most likely to be interosted were busy with the1r own affalrs; the Moroccan government was on the verge of collapse; the French people were in the right frame of mind; and France had a forelon minister oapable of leading the way. The French had had occasion for close contact w1th the Moroccan government for many yoars. As far back, in fact, 281845 a treaty had been signed between the two countries which roughtly fixed the boundary line 
between Algeria and Morocco. The unrest in the latter country had given rioe to innumerable raids in Algeria by savage tribes. The French complained loudly and demanded protection, which the sultans were in no position to give. Accordingly, the local Algerian authorities often took it upon themselves to puraue the tribes across the indefinite boundary into their own country in order to subdue them. Then it would be the Moroccan Government's turn to complain. Friction was almost continuous and sharp words were often visited by the French upon the sultan. Such was the caso in 1801, owing to the fact that attacks by Moroccans on Algeria had increased. This time the Sultan appealed to Groat Britain and Germany for a1d. The kission he sent to Lond on was merely warned by Lord Landsdorne that if the Sultan could not keep order, France would have to defend her interests. 1 Germany was indifferent, though she was not to remain so for long. In the end, a new treaty was a rranged between France and Morocco, when the latter sent a special mission to France to settle the boundary trouble. But the treaty of 1901 left the boundary as uncertain as It had been, for Delcasse had no intention of creating a carefully isolated Horocoo. Having an Inderinite

1.9.P.Oooch, H1story of Modern Europe, 1878-1919, 341. Hereafter this work WIII be cited as Gooch, Modern Europe.

2. Anderson, Moroccen Cris1s, 14. 
border line between the two countries was for France I1ke having a foot in the door.

There were several interesting provisions in this treaty, interesting in the light of French pollcy. one created a zone between the two countries within two Iines drawn through what was definitely known to be Moroccan and Algerian territory. The tribes living inside the zone were themselves to choose whether they wished to reside under French or Moroccan authority. Moroccans and Algerlans were to be free to enter the zone for commercial and o ther parposes. Moreover, tribes of either country owning pasture lands in the other might still use them. Each country was to appoint two comissioners to settle border disputes. Each was privileged to set a line of posts for defense purposes in territory definitely 1ts own. ${ }^{\text {. }}$. In 1902 two other treaties were negotiated by Frence with Morocco. They. 1aid down a complete program of military, political, and economic cooperation between them. 2 .

It was quite apprent that the sultan could not hope to main tain order in and along the frontier of Moroccowithout help; so he requested the aid of a few

1. Ib1d.,16 from Ministere des Étrangeres, Document diplomatique, affaires du Maroc, 1901-1905. THereatter this Livre jaune will be cited $\mathrm{s}$ L.f. 1901-1905) 15ff., No. 20 and annexe.

2.Ib1d., 17, from L.J.,1901-1905, 26ff., No.24; $33 \mathrm{IT}^{\prime}$. No. $27 \mathrm{f}$. 
French mllitary instructors, who were supplied him. A Frenoh bank also advanced him a small loan. At the same time, however, the Sultan sent another mission under one of his advisers, Kald Maclean, and ex-British soldier, to Great Britain and germeng to secure holp in stopping French interference. The Mission met with the same fallure as the earlier ones. ${ }^{1}$. When 1903 rolled a round bringing with it the revolt in Morocco already mentloned, the sultan found himself in such dire stralts that he was glad enough to accept the loan of $22,000,000$ francs guaranteod on the custom which France advanced to him for the purpose of oarrying out reforms. ${ }^{2}$. Thus unwillingly he began to fall in with Dolcasse's policy of "Paclflo penetration", which it was hoped should some day bring Horocco completely under French control. Although the French Foreign Minister's instructions to the French representative at Tangler carefully required that the sultan be as sured of French respect for the sovereignty and integrity of his land, and of France's desire to give him nelghborly assistance, they also required the representative to support all enterprises, philanthrople, comercial and industrial, tending to augment French influence in Morocco. 3 .

1.G.T.Gooch \& Harold Temperley, eds., Brit1sh Documents on the Origins of the War, II, 272F., No.328. Hereafter this wark wIII be cited as B.D.

2. Anderson, Moroccan Cr1s18, 18, fr. I.J., 53ff, No.30 3.Ib1d., 16, from L.j., 1901-5, 18ff., No. 21 . 
In the moantime, whet of the other nations that might have reason to be intensely interested in France's relations with Morocco? Delcassé by no means overlooked the possiblity of competitors suddenly confronting him, however preoccupled they might be at present with their own affairs. Securing the goodw111 of these nations became, therefore, a very importat part of his polley. He won the neutrality of Italy, spoin and areat Britain by ostablishing ententes with thew. The negotiations bringing about these understand-. ings proceeded for the most part simultaneously, but they $\mathbf{T l l l}$ be discussed separately for purposes of clarity. Delcasse's first triumph of diplomacy was the entente established with Itais in 1902. In I881 Italy's attitude toward France had been considerably embittered by the latter's selzure of Tunis which Italy coveted greatly. The hard feolings thus engendered resulted in a ten jear tariff war between the two countries, and in Italg's entry into allianco with Germany and AustriaHungary. Italy soon disoovered that the Alliance which she had entered mostly 28 a protest directed toward France was of I1ttle use to her, that she even suffered becanse of 1t. ${ }^{1}$. Wherefore, she undertook in 1896 to bring about a rapprochement with her nelghbor on the north. The troublo over Tunis was settled that same

1.B.D., I, 285, No. 355; 286, No.356. 
year. Two years later the tariff war botwoen Italy and France was ended by a commercial treaty. 1 .

In 1898 Delcassé, quick to foster the new situation, visited Rome. Itoly having given up all hope in regard to Tunis had accordingly turned her eyes on Tripol1 as a subst1tute. Delcassé procoeded to use the object of Italy's new desires as a means whereby he might win Italian recognition of France's preferential position in Morocco. Ho was entirely successful. On December 14, 1900 , a secret agreement was reached between France and Italy. According to the treaty Italy rocognized that action taken by France to exercise and sefoguard the rights resulting for her from the proximity of her territory to Morocco, would not be considered prejudicial to the interest of Italy as a Mediterranean power. Furthermore, in case a modification of the political and territorial status of Morocco should result, Italy would 'nreserve for herself, as a reciprocal measure, the right of eventually developing her influence in Cyrenatc Tripolitaine:" 2 . As one may readily seo, the above statement was somewhat vague and gave to Italy a negative sort of assurance.

1.Anderson, Moroocan Crisis, 20, from D1e Grosse Pol1tik der Eropaischen kabinette, 1871-1914, XVIII, 7I5, No 5833. Lerearter this Tork wIIl be cited as Q.P.

2 Anderson, Koroccan Crisis, 22, quoting L.j., 1900-2, 3f., 10. I, hnnexes I and II. 
Italy was patently anxlous for better terms in regard to Tripoli. There was, however, from the French standpoint, at least, one obstacle which had to be leaped or got around in some way. This was Italy's obligation as party to the Triplo Alliance. France wanted to make sure that the Alliance, renewable in 1902, should contain no clause aggressive toward her. In June, 1901, the Itallan Forelgn Minister verbally promised the French Ambassador to Italy that the renewal treaty between the central Powers and Italy would contain nothing hostile to France, in return for which declaration of Italy's rights in Tripoli were put on the same basis as those of France in Morocoo. The burden of his conversation was embodied in notes exchanged between France and Italy on November 1, 1902, which constituted a formal, but secret agreoment containing the following clause Insisted on by Delcassé:

" In case France (Italy) shall be the object of a direct or indirect aggression on the part of one or several Powers, Italy (France) will preserve a strict neutrality. The same will hold in case France (Italy) as a result of direct provocation is forced to take, for the defense of her honor or socurlty, the inltiative of declaration of war." ' 1 .

1.Ib1d., 31, quoting L.1., 1900-2, 4f.,No.3;6, No.5. 
Thus ended the twenty year quarrel between the two Latin nations, publicly announced by the $v 1$ att of President Loubet of France to V1ctor Emanuel in 1904. Though Italy had obtained what she wanted, a recogn1tion of her claims to Tripoli, yet she found herself with a foot in each international camp, a position which was to prove a rather uncomfortable one, as we shall se日. Delcassé gained more than the direct end he had in view, that of settlement of the Morocco question as far as Italy was concerned. The Triple Alliance, already weakening, had received a severe blow desplte the Germen Chancollor's famous remark to the effoct that in a happy marriage a husband does not mind his wife's indulging in an innocent extra dance. I. What is more, the drawIng of Italy away from Germany marked, if not the end. of French isolation, (a thing of the past by 1898,) at least the beginning of German isolation. The establishment of the entente with spain was accomplished at the end of a rather rocky diplomatic road. Delcassé realized that spain was ent1tled to a special position in Morocco as was Frence. Spain's proximity to Morocco, her history of past attempts at conquest of the country, her economic interests there and the number of Spanish in Morocco, which was greater than that of ang other forelgn nation, had all testified to the fact that Spain could not be 1gnored in any disposition of Morocco among the Powers. Spain had, however, 
been satisfied with the status quo and had not reciprocated warmly the advances made to her by France in 1898-1900. 1. Nevertheless, when she saw the progress France was making in the region back of Morocco, she awoke to the danger to spanish interesta there, ${ }^{2}$ and decided that if the territory was to be divided, spain would claim the northern part. It was spain, then, who opened direct negotiations with France over Morocco, but 1t was France who gained the wost through Delcasse', who was unwilling that spain should have as much territory as she desired. The negotiation dragged along for some timo. Finally, in 1902 an agreement was reached upon three main beses:

(1) The tro countries adhered to the principle of the pacific penetration of Morocco;

(2) France promised Spain diplomatic support in the execution of the treaty;

(3) Spain was to recelve as hor sphere of influence almost all of the old kingdom of Fer, including the capitol and Tangior in the north;

France was to get the rost. 3 . Unfortunately for Spain, a it proved later, the agreewent fell through because the conservative government which had just come into power in Spain foared the att1tude of areat Britain who did express her desire to be

$$
\begin{aligned}
& \text { 1.B.D.,II, 258, No.311. } \\
& \text { 2.Ib1d., 259, No.314; 260, No.316. } \\
& \text { 3. Ib1d, II, 279, No.336; 306ff., No.364;III, 33, } \\
& \text { No.34; 35, No.37, No.41; 31f., No.32. }
\end{aligned}
$$


considered in the discussions over Morocco. Negotlations lapsed for a time while Delcassé began to treat with areat Britain. Throughout the Anglo-French negotiations spain revealed her anxiety lest Span1sh interests should not recelve due consideration, She thought that she should have been included In the discussions over Morocco.1. In 1904, negotiatlons were reopaned between France and Spaln, and a new agreement was reachod, although Spain considered the terme given her much inferlor to those proffered her in 1802. Spain particularly objected to a clause which Delcassé at the last moment wanted included. By it she would be precluded from taking any action in her sphere of influence until the status quo in Morocco should come to an end. Spain felt that this prohlbition upon Spanish action would give France an excellent chance to establish herself in Morocco in such a manner that Spain could never claim that the political status of Morocco had been altered, and thus be able to assert her rights to a sphere of influence?. Nevertheless, spain had to accopt protty much what France and Great Britain between them were willing to concede to her.

The Convention between France and Spain, which was secret, was signed at Paris, October 3, 1904.

$$
\begin{aligned}
& \text { I.Ib1d., III, 39, No.44. } \\
& \text { 2.Ib1d., 39, No. } 44 .
\end{aligned}
$$


According to it Spain adhered to the Anglo-French agreement of the previous April. There is no need to discuss here the varlous articles of the treaty. Suffice It to say that such subjects as the boundary line between the two spheres, joint economic enterprises, mliltary action, and contraband in Morocco were dealt with. The clause Declassó had desired was also incorporated and Spain promised not to alienate the territory she would receive.1. By this treaty the rapprochement between France and spain became a reality. Delcassé had gained another nation's recognition of France's preferential claims in Morocco.

During the long drawn out spaniah negotiations, conversations with Great Britain were begun in 1903 anent the establishment of cordial relations between Fngland and France. Delcassé was keenly aware of the necessity of gaining British approval of the alms he wished to achieve in regard to Abd-el-Aziz's helpless country. He had made advances to Great Britain earlier than 1903 but they had met with slight success. 2. There were a number of factors in the business not calculated to make Delcassé's task an easy one. Franco was still smarting from the injury to her pride suffered at the hands of the British in the Fashada incident of 1898 . Furthermore, both countries were the respective allies of two nations at swords points in the Far East,

1. For the terms of this treaty see Ibid.,49, No.59. 2. B.D., I, 163, No .188;171, No .198. 
namely, Rusala and Japan, Bes1des, British Influence In Morocco was growing apace. Delcassé was anxlous to prevent an Anglo-German alliance?. Hence he cult1vated assiduousiy German friendship and twice in 1801 made advances to Germany to establish an accord.2. Both attempts were fruftiess but were offset by the fallure of the Anglo-German agreement to meterialize. As it turned out, the business and political groups In Great Britain and France eased the French Foreign Minibter's path by agitating for improved rolations between thelr respective nations.

In May $1903 \mathrm{King}$ Edward pald what turned out to be a very auccessful visit to Paris, which was returned by President Loubet and Delcassé two months later. The negotiations begun then and continuing unt11 April 1904 amounted to little more than mere bargaining. France was domina ted by the desire to gain British recognition of her peculiar interest in Morocco; Great Britain, on the other hand, saw in this situation a splendid opportunity for the settlement of the Egyptian problems. Although the Russo-Jepanese war breakIng out in February,1904, complieated matters, an agreement was e ventually attained as a result of compromise. Three documents comprised the Accord of Apr11 8, 1904. We are interested in the third agreement which concerned

$$
\text { 1. Ib1d., 162,10.187. }
$$

2. Anderson, Moroccan Cris1e, 45, from G.P.,XVIII, 28ff, Nos.5353-95. 
Egypt and Morocco. As in the case of the spaniah agreement there is no need to go into thed etalls of this treaty. The significant fact 1s, that each of the two countries agreed to ourrender 1 ts rights and interests in the backward nation coveted by the other; that is to say, France would keop her hands off Egypt; Great Britain would do the same in regard to Morocco. Supplementary to the public agreement there were five secret articles which boldiy lald down a program of action to be taken in case the sultan should cosse to exexcise authority. Great Britain promised to France full diplomatic support in carrying out the program. As Mr. Anderson has strikingly sald, "The doctors were agreoing upon a division of the patient's property before they began to operate." $\mathbb{L}$. Frence's secret agreement with spain and Great Britain were quite obviousiy in violation of the open door principle.

When we come to a conalderation of M. Delcassé's policy in regard to Germany, those who are of a I1terary turn of mind mey possibly be reminded of the great characters in Shakespearean tragedy whose unhappy ends were often the result of a traglc flaw in their personalties. M. Delcassé seemed almost to be the victim of such a flaw, although luckily for the immediate peace of

$$
\begin{aligned}
& \text { 1. B.D.,II, 373ff., No.417. } \\
& \text { 2. Anderson, Moroccan Cris18, } 106 .
\end{aligned}
$$


the world no fatel event occured as a result of 1 t. To be sure, Delcassé had made an honest effort to win the friendship of cermany. He had even attempted to bring about an eccord. Nevertheless, he seems to have completely under-estimated the interest which dermeny might manifest in the future of Morocco, though he might have suspected 1t. Be that as it may, he very casually informed Germany of the Anglo-French agreement through the Cerman ambassador to France. FearIng that formal announcement would provoke discussion, he no doubt hoped that his comparative silence would gain a tacit acceptance by Germany of h1s pollcy. Whatever Delcassé thought, ho continued pacific penetration throughout 1904. The loan made to the sultan had brought the Moroccan customs almost entirely under French control. Further acts of banditry emphasized the pressing need for reforms in Horocco and gave France additional opportunities to take the lead in introducing them. The French government proceeded to outline complete plan of reform. M. Saint-René Talilandier was dispatched in 1905 to Fez to persuade the Sultan to adopt the plan. of course, the French onvoy was carefully instructed to impress upon the Sultan that prance was acting merely in a friendiy spirit in offering to holp him ostablish a strong government, a thing be was to understand was possible only 
through close cooperation between the Moroccan and French gorernments. ${ }^{1}$. According to the plan French officers were to help train the Moroccan pollce so that order might be restored. The scheme of reform also included the bullding of roads and telegraphs, as well as the establishment of a state bank. 2 . The envoy did not find the sultan in a very recoptive mood, although the latter conceded the practicablilty of some of the reforms. It was necessary, the sultan sald, for them to be discussed with the Maghren. While these discussions were going on and Rene-Taillandier was tolling to wring acceptance from the Moroocans, Germany suddenly awoke to what was going on and uttered a clastion protest.

The German policy throughout the peri od of the Moroccan crisis and the Conference of Algerclras was most uncertain and therefore difficult to fathom.3. The direction of German foreign policy seemed to be a case of too many cooks spolling the broth. The Kalser insisted upon taking a hand in the conduct of forelgn relations with the result that Count Bülor, the German Secretary of state for Forelgn Affalrs, and later Chancellor, spent a good deal of his time correcting the mistakes of the Emperor. Furthermore, though Bülow had Idess of his own, he was constantly open to the

\footnotetext{
1. Gooch, Modern Europe, 348 from L.j.,1901-5, 1791f, No.299.

2. Ib1d.

3. BD.III, "General Report on Germany for 1906,

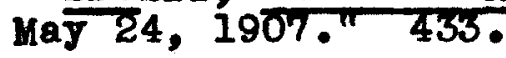


persuasive Influence of Baron Von Holstein in the Forelgn off1ce, whom many considered as almost a psychopath. There was no continuity, no real direction to German policy. Consequently, other nations could not be expected to know cermany's intentions, if Germany herself apparently did not know what she wanted.

Although at first cerman government was friendly to the Anglo-French agreement of April, 1904, 2. later In the year the German Ambessador to Great Britain in conversation with Lord Lansdowne, the Foreign Secretary, stated that cermany wanted the status quo and the open door to prevall in Morocco, and that she meant "to uphold any rights which she was entitled to claim in Morocco under existing treaties".3. At the time the Anglo-French agreement was concluded Bulow saw no cause for alarm, while the Kaiser told KIng Edward thet Morocco had never interested him. 4 This attitude on the part of official Germany may account in part at loast for Delcassé's fundamental error in not reaching some defi-

\section{Ib1d., 429 .}

2. Anders on, Moroccan Cris1s, 14lf., quoting Bernard von Bulow, Reden, (LeIpz1g,1903), II, 74,84, 901 .

3.B.D., III, 53, No.62.

4.Ibid., IV., 1, No;I:Ibid.,2, No.2; Sidney Lee, King Edward, VII, II, 292ff., also G.P., XIX, $186 \mathrm{ff} ., \mathrm{Nos} .6038$ and 6040 . 
nite understanding with Germany concerning the future of Morocco. However that may be, the Pan-Cermans soon raised a hue and cry throughout Germany to the effect that German economic interests were being sadIf neglected and that Germany should uphola her rights.

The sending of the French envoy to Fez was the occasion for a sudden change of German forelgh pollcy. The German ohargé at Tangler, Iuhlmann, remarked thet France had made a "bad mistake" in thinking that the agreoment with Spain and Great Britain settled the international side of the question. Germany hurried to bolster up the Sulten in his opposition to Frence. She demanded the status quo.

Holstein, at this moment, conceived the 1dea of the Kaiser's paying a visit to the Sultan by way of making a political demonstration which should bring the Moroccan affair into prominence, be of benefit to Germany's economic interests in Morocco, and emberrass Delcassé. Bulow, who by this time was German Chancellor, accepted the 1dea at once. The Kalser, however, was not in sympathy with the plan, and had to be persuaded to take part in the affair. Even at the last moment when about to leave his yocht at Tangler, March 3,1905, he tried to use the roughness of the sea and the sort of horse he should have to ride as excuses for not pro- 
coeding with the demonstration. As for the Moroccans, they apparently looked forward to the Emperor's visit as a possible check upon trench designs . Bulow in a four page telegram had taken pains to instruct William II as to what ho should say in the spoeches the latter would make at Tangler. The Kaiser was to encourage the Moroccans in their resistance to France and arouse uneasiness in the Prench, but he was not to commit Germany to anything definite. As reported, the Kaiser's speech to the Sultan's representative ran, as follows: He declared that "he had great interest in the welfare and prosperity of the Moroccan Empire, that he visited the Sultan as an Independent ruler, and that he hoped under the authorlty of the sultan a free Morocco would be opened to the peaceful competition of all nations with out monopoly or exclusion." 2.

The Tangler demonstration proved to be a blunder, a diplomatic fallure of the first order. This was for two main reasons. In the first place the Emperor,, whom King Edward called Europe's "enfant terrible", talked too freely and thus bound Germeny more tightly in respect to her Moroccan policy than Bulow had wanted; ${ }^{3}$ in the

1.B.D.,III, 58, No. 68 .

2. Anderson, Moroccan Crisis, 193f., quoting the version of the speech published in Allgemaine Ze1tung (Munich) April 4,1905.

3. See Bulow's Instructions to the Kalser, And erson, Moroccan Cr1s18, 190f., quoting from Q.P., XX,272ff., No. $65741 \%$. 
second place the visit cemented the entente between Great Britain and France, the least desirable happen1ng for Germany. But the fat was in the fire and it was to fry for a long t1me. Delcassé and the French pollcy in Morocco had been openly challenged.

Before going further, let us see if we can draw at least a fer tentative conclusions with regard to the motives which have la in behind Germeny's forelgn policy. It is evident onough, I think the Germany when she became clearly aware of France's intentions in respect to Morocco, was truly concerned about the future of her economic interests in that country. Consequently, she demanded the maintenance of the status quo and the open door. But it was also ovident that the status quo was impossible. Cermany revealed her recognition of this fact when she complained about France's fallure to consult her in regard to Morocco. What, then, did she want? Protection of her economic interests was certainly not the sum total of her desires. Varlous possible explanations of her pollcy have included Germanj's desire to maintain her prestige, to gain compensation somowhere? to acquire naval bases and coeling stations, to establish a Germen Morocco whtch should neutralize French Algeria in case of war, to become Mediterranean power, 2 and to destroy the Entente

1.E.Brandenbur From B1smarck to the Woted War; a H1story of German Fore1gn Polloy, 1870-1914, 2297.; D:D.D..III, 2201., No.20\%. 2.B.E.Schmitt, England and Germany, 1740-1914,233. schmitt says Germeny never admitted these things. 
Cordiale. We shall keop these possibilities in mind

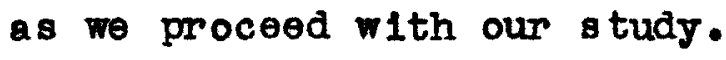

By Apr11, 11, the French envoy at Fez reported that the Sultan had consented to have his troops at Tangier, Rabat, Casablanca and Ujda organized on French models. The progress he had thus made ras completely undone, however, upon arrival of a Germen envoy, Count Tattenbach, on May 13. In about two weoks the Count had so influenced the sultan that the latter rejected the French scheme of reforms.. A British misston which arrived a couple of days after was unable to reverse the decision. The sultan gave as an explanation of his conduct the excuse that he could only accept the French plans if ratifled by the Powers.2. That did that mean? The international friction in Morocco had reached the point where a way out of the difficulty had to be found. Was the Sultan suggesting one, and if so, was it his own ldea and would it work?

1.Anderson, Moroccan Cr1s1s,225, from G.P. XX, 392 , No. 6672.

2.A.W.Ward and G.P.Gooch, The Cambridge History of British Foreign Policy, III, 34I. 
Chapter II

THE WAY OUT: AN INTRRNATIONAL CONFERENCE 
Chapter II

The way out: An International Conference.

The sultan's way out proved to be an international Conference of the powers signatory to the Madrid Convention of 1880. The conference should pess upon the French proposals. The Sultan's move was patently of German origin. 1 The German press had for some time been advocating a conference and early in April before the German envoy reached Fez, the German government sent out circulars to the powers to sound their attitude toward such a meet1ng. 2 .

The story of the period prior to the actual holdIng of the Algeciras Conference is as necessary to the story of the Conference proper, as a key is necessary to open a locked door. To omit a discussion of the diplomacy of this period would be like arriving at a play at the beginning of the last act and expecting to understand what the characters were about without knowledge of what had transpired earlier. In considering, then, the diplomatic rolations leading up to the Conference of Algeciras, we see that they fall rather naturally 1nto two mejor phases: first, the period of Germany's struggle to bring the conference about; second, the period of the struggle by the powers (chlefly French and Cerman) to agree on the program. These divisions

$$
\begin{aligned}
& \text { I.B.D.,III, 88, No, } 106 . \\
& \text { 2.Ib1d, } 66, \text { No, } 78
\end{aligned}
$$


made in something so fundamentaliy continuous as history may be excused perhaps on the ground that they make for clarity, always at a premium in any consideration of European pol1tics.

The action teken by Gormany in the shape of the Tangler demonstration required to be followed up, hence the circular note sent to the powers. The reaction which the German govermment received for 1 ts trouble was not very sat1sfactory. Austria-Hungary and Russia disapproved of Cermany's action. The other nations tried to evade the is sue and hung back to let France take the lead. Spain declared she could not adhere to the cerman proposal unless France and Great Britain agreed to do so. The sudden looming of the Cerman M1chael on the French horizon frightened the country into a criticism of the pollcy of 1 ts Forelgn Minister, Delcassé, who heartily opposed a Conference and sought to reach a direct settlement of the misunderstanding between Germeny and France. Italy also urged direct settlement but Germany responded to Delcassés overtures by insisting on the Conference. The motives behind Germen actions are well set forth in instructions given by Bulow to count Tattenbach on April 30, 1805. In explaining Germany's desire for a conference, he says:

1. Anderson, Noroccan Cr1s1s, 206 from G.P., XX, 317, No. 6612; 2771., No. 6577. 
"Even 1f, therefore, France were inclined to permit us to conquer a part of Morocco, we would for the present perhaps not be in a positi on to take advantage of this overture. In reality, we are confronted with the alternative either of relinquishing Morocco now to France wh thout adequate compensation to Germany, or of working for the extension of the ilfe of the Sherifian Empire In the expectation of turn of events favorable to us. Thus, I perce1ve your important task to be in holding the future free for the profit of German interests. I sum 1t up in stating that you should bring the sultan to declare that he could consider the French demands only if they were advised by a conference of all the signatory Powers. The reference to the conference I consider for the sultan the easiest and for us the most favorablo form of refusal. That the sultan refuse the French demands is naturally the main thing." 1 .

In speaking of maintaining the state of Morocco until a favorable turn of events, and of keeping the future free, Bulow probably had in mind the time when cerman public oplnion should be solidly behind a policy of colonial acquialtion and the time when the cerman navy should be capable of winning and preserving a colonial Empire. It 1s evident also, I think, from the instructions, that 
Bulow was confident that no Conference of the powers would accept the French plan of reforms. Unfortunately, at this time there developed in France much opposition to Delcassé and his pollcies. The opposition resulted from a number of factors, such as Delcassé's long tenure of office, his independent methods, and the onmity between him and the French Premier, M. Rouvier, who belleved that France should treat Germany and Great Britain alike in regard to Morocco. Rouvier ouggested that an exchange of notes between France and the powers might be all that was necessary to settle the trouble, but his proposal met the same fate as Delcassés proposal for direct settlement between the two nations. The Kalser's excuse for German refusal to settle directly with France was that cermany was championing the caues of the world. As for Great Britein, she could not understand why there should be so much international difficulty over what the Marquess of Lansdowne pleased to call a "diplomatic oversight" on the part of Delcassé?. In the meantime, Germany suggested that France herself call a Conference. She naturaliy refused to do so. Then the Sultan on May 30, 1905 1s sued his own invitationsto a conference to consider the French plans of reform.

\footnotetext{
1.J.B.Bishop, Theodore Roosevelt and H1s T1mes,I, 469. Hereafter this work will be c1ted as B1shop, Roosevelt, I.
}

2.B.D.,III, 68, No. 83 . 
A little earlier, Germang had approached the United states, urging her to persuade areat Britain to accept a conference. President Roosevelt replied that the United states had not enough interests at stake to warrant entangling herself in the matter, but that sho was not averse to trying to holp the establiahment of a friendly feoling between Germeng and Great Britain, provided it was clearly understood that the United States was not taking sides. I. Great Britein, however, remalned hostile to a conference.

Delcasse, supported by Great Britain, clung to his policy of opposition also, but his colleagueswere frightened as to the outcome if he continued thus. Germany threatened war and demanded the elimination of the Forelgn Minister. Delcasse ras convinced that Germang was bluffing, but Premier Rouvier thought differentis when Prince Henckel von Donnersmark in visiting Parls remarked that "If you (the French) think that your Forelgn Minister has engaged your country in a too adventurous path, show it by separating yourselves from him, and above all by giving your foreign pollcy a new orientation. The Emperor does not wish for war, but if you aro beaten you will be bled white. "r'. The British Government apparentiy did not foar war, since she believed cermany far too weak on the sea to attempt such a thing. 3.

$$
\begin{aligned}
& \text { I.B1shop, Roosevelt, I, } 47 \mathrm{Tf} \text {. } \\
& \text { 2.Goo h, Modern Europe, } 356 . \\
& \text { 3.B.D., III, 68, No.82. }
\end{aligned}
$$


Be that as it my, the French Cabinet was sufficiently alarmed to present a hostile front to Delcassé at the decisive Cabinet meoting of June 6, 1905, when supported only by President Loubet, Delcassé was forced to resign. In commenting upon his fall to the British Ambasaador to France, Delcassé said that he had been ready to mako commercial concessions to Cermany if she had been willing to talk, and though he would not have ylolded anything politicaliy or territorially, he would not have done anything in Morocco which would have jeoperdized Germany's treaty rights there. Further, if England, France and Spain stood together, he said he did not belleve that Germeny would attack France. Moreover, Italy had bound herself to remein neutral as regards Morocco and not oppose France.I. It appeared to be evident thet cermany ras alming at more than protection of her treaty rights. Now, as to the effect which Delcasse's fall had upon the international situation and the nearnes of the powers to a conference: It seemed to be a triumph for Gorman diplomacy to be thus able to eliminate the chief obstacle to 1ts schem. At least it must have seemed 80 5o the German Emperor, for he Immediately raised ChancelIor von Bulow to the rank of Prince; it looked as if he meant to celebrate the initial success of Germany's Moroccan policy. However, an interesting thing happened,

\section{Ib1d., 78, No. 96 .}


and no doubt, a startilng one for Germany, the fact that only a slight change in French forelgn policy was noticeable upon Rouvier's assumption of the office of Foreign Minister. I. Rouvier continaed to demond a direct understanding with Germeny, but he approached his opponent in a more subtle way than his predecessor. He informed the Cerman Ambassador that he had no liking for a conference, but that if he did accept the Sulten's Invitation, there would have to be a preliminary understanding with Germany. He said, "Wo think a conference dangerous without previous agreement, and useless with $1 t^{\prime \prime}$ (Italics mine): The French, however, did not definiteIy refuse acceptance.

W1Iliam II was inclined to favor Rouvier's suggestion of an exchange of notes between the powers rather then a conference, but not $80 \mathrm{Bu} l 0$, who once more appealed to President Roosevelt to take hand in the matter and persuade France and Great Britain to agree to a conference. He represented the conference to Roosevelt in the light of an alternative to war. The latter, never very well Informed on European affairs, seems to have accepted the Chancellor's interpretation of the situation, for he reluctantly promised to do what he could. Roosevelt decided it would be useless to speak to England for, to quote him,

$$
\begin{aligned}
& \text { I.Ib1d., 97, No. } 126 . \\
& \text { 2. Gboch, Modern Europe, } 3579 \text {. }
\end{aligned}
$$


"I felt that if a war were to break out, whatever mifht happen to Frence, Fingland would profl t immensely, while Cermany would lose her colonies and perhaps her fleet. Such being the case, I did not feel that anything I might say would carry any welght with England, and instead I made a very earnest request of France that she do es the Emperor desired (Bulor, of course, spoke through the Emperor) and agree to hold the conferencen'.I. While expressing to France the "real sentiment" which he had for her, ho impressed upon her the danger of war to the French, pointing out that in such a contingency Great Britain could help France but littie on land and the the had no reason to belleve that a conference would allow Cormany unjustly to attack French interests. In oddition, he not only promised not to accept an invitation to a conference, except on condition of France doing likewise, but also promised that if he went he would be absolutely Impartial, standing firm a gainst any German attitude smacking of unfalrnoss.2. on June 23 France gave in. at once Roosevelt suggested to Germeny the danger of war to them also, that Germany could not be sure she would win, since France was bound to be supported. He proposed that a program of the conference be arranged between Germany and France, and hinted thet inasmuch as France had accepted the conference it would be advisable on Germany's part to make a few concessions to her, else the Kalser's "high and honorable fame might be clouded" should war result.

I.B1shop, Roosevelt, I, 483f. 2.Ib1d., 478. 
When Roosevelt's mediation is closely examined, it will be seen that as a result of 1 t Germany, by acceptIng Roosevelt's suggestion that a program be agreod upon before the Conference, was really the netion which backed down. France had already accepted the Conference in principle when Rouvier stated on June 21 that if Prance accepted the Sultan's Invitation there would have to be a preliminary understanding. Germany, who had at first demanded France's acceptance of the conference without any sort of discussion prior to its meeting, now found agreement on the program acceptable, but ins is ted it should follow France's assent. France, on the other hand, demanded an agrement on the program before giving her formal consent to attend a conferencelo France wanted to keep her hands free; she wanted to be able to back out of the Conference if a program to her liking could not be decided upon. At this junoture, Roosevelt once more ceme to the rescue. He proposed thet France and Germany accept the following: "The two governments consent to go to the Conference with no program, and to discuss all questions in regard to Morocco, save, of course, where either is in honor bound by a previous agreement with another power." cermeny accepted readi1y; France anly after Rouvier despalred of being able to avold a conference. An accord was signed by the two

1. Anderson, Moroccan Cr1s18, 252 from G.P., XX, $485 f$., No 6746 . 2. Bis hop, Rooseve It, I, 485. 
Powerg July 8, 1905; by the terme of which France accepted the Conference on the understanding with Cermeny that her rights be respected and that her arrangements w1th England and Spain not be questioned nor the open-door policy altered. ${ }^{l}$. Four days later Great Britain agreed to the Conference, a Ithough, she had backed France in opposition to it up to the very last.

one nation in particular felt great relief over the accord. That nation was Italy. Though sho cared I1ttle enough zbout a conference, she cared less about a war which would have revealed her anomalous position in glaring light. It should be mentioned that the Emperor, In thenking Roosevelt for his good of 1 1ces, Instructed the German Ambassador to the Unitied States to say that "In case during the coming Conference differences of opinion should arlse between France and Cermany, he in every case w1ll be ready to back up the decision which you (thoodore Roosevelt) should consider to be the most falr and the most prectical."

The accord of July 8 th won for Cermany Frenoh acceptance of the conference without a preliminary agreoment on a program, but France was protected by the guaranteo that her arrangements with spain and Great Britian

1. Foreign Relations of the United States, 1905, 58 Cong., 1 ses8., House of Repr.; Doc. 1., sertal No. $4941, P 668$. 2.B1shop, Roosevelt, I, 487 . 
were not to be questioned. Thus, her speciel posits on in Morocco was rocognized.

Negotiations regarding a program were begun at once, lasting sbout three months. The discussions soon came to revolve around several controverted polnts. Police and Pinencial reforms were the main is sues at stake. In regard to the first, France was determined that the regulation of police on the Algert an border be settled directly between her and Morocco, whereas Cormany considered that the question of barder polloe should be an International one.1. Bulow was willing thet the military and police mandate in Yorocco be divided among the Powers in such a way that France recolve the excluItre mandate for the frontier region, provided that Germany recelve a mandate for some Westerm Morocoan coastal towns from Rabat south. ${ }^{2}$. This was naturally unacceptable to France; hence, Germany clung to entl re internationalization of police. Cermany al so demanded that the conference met at Tangler; twice France refocted the proposal. Relat lons between the two nations were further strained (I) when the Moroccan government granted to a German flrm on July 30 th a contract for bullding a breakwater in the harbor of Tangter and (2) whon a group of derman banks loaned the sultan 10,000,000 marks. It was

$$
\begin{aligned}
& \text { I.B.D., III, 131ff., No. } 174 . \\
& \text { 2.Anderson, Norocean Cris1s, 262, from G.P., XX, } \\
& \text { 525n.; 450, No. 67I8; 52517, No.6774. }
\end{aligned}
$$


rumored that Tattenbach, the Cermen envoy, helped to presuade the Moroccan government in these matters. Though he upheld the transactions agalnst French complaints, Bulow reprimanded Tattenbach because his actions had complicated the negotiations. In the mant1me, Spain's offer of a town in southest spain as a meeting place recelved no roply from Germany.

At about this point, however, Chancellor von Bulowrecognized that cermany must alter her policy or lose face in the family of nations. Therefore, he sent to Paris one Dr. Rosen who had advised the Cerman government to ake concession on the meeting place and to withdraw her demends in regard to regulations of police on the frontier. But at the same time cermany should try to obtain an exact definition of the limits of the frontior region. France should then give way on the question of the mole and the loen. When he got to Paris, Rosen decided to make a concession by Germany on the frontier question contingent upon France's disclaiming any intention to control the financial or police reforms in the whole of Morocco. The French government refused, but offered to include in the discussion at the Conference, matters which, though not pertalning directly to Morocco, Cormany was Interested in -. such as the Bagdad and Camerun railmay. Cermany, however, rejected the offer. 
At this functure, came the intervention of Count Witte, who was returning to Russia from Portsmouth, Maine, where he had represented Rusis in the peace negotlations between that country and Japan. Russia was anxious to negotiate a loan with her ally, France, an impossibllity until the business concerning the conference was cleared up. He stopped off in Germany and urged the German government to give way. The German Ambassador to France, Radolin, was willing, as was Emperor William who was sick of the Moroccan affalr. The German government declded to heed Count witte's advice, for, after all, it was not in a position to right prance. The understandIng was reached september 28. The program of the conference was to include:

(1) Police reform and suppression of contraband traffic in arms by way of an intermational accord, except in the frontier region wich should be the exclusive concern of France and Moroceo.

(2) creation of a Moroccan State bank;stablization of Moroccan monetary system; advancement of funds to pay pollce and carry out urgent publ1c works.

(3) Improvement of methods of collecting the oustoms and ralsing revenues.

(4) No alienation by the Sultan of any public service to the profit of particular interests. 
(5) Principle of adjudication without regard to nationality to be followed in giving contracts for construction of public works.

(6) Meoting of the Conference at Algeciras in spain.1.

There was a supplementary understanding which settled the differences which arose over the cermen contract for the mole and the Cerman loan. Rouvler took pains to declare that aside from the above agreement, he was not bound on any point.2. The sultan had little likdng for the program presented to him but finally gave his consent on october 22. December 1 he sent out a clrcular letter of Invitation to the conference. The invitation was accepted by all the powers, including the United States, signatory to the Madrid Convention.

During the time which elapsed between the agreement on the program and the opening of the Conference, the powers chiefig interested took stock of their positions and the outlook for them the conference. The german government, in particular Prince Bulow, considered there was every reason to be hopeful about the Conference from the German standpoint. Germany looked for the support of Amoricr, knowing that Roosevelt upheld the open-door policy. She expected no interference from Russia and had secured a promise of support from her ally, Austria-Hungary. Further1.B.D., III, 142ff., No.184; 146f., No.188. 2 -Andre Tardieu, Laconference D'Algerciras, 44f.; als o Anderson, Moroccan Cris1s, 273 from L.f., 1901-5, 305f., Nos. 349f. 
more, Corman had plaged upon Spaln's jealousy of France in Xorocoo to the extent of prerenting the appointment bJ Spein of the antf-corman Senor V1lla-Urmutla as a delegate to the Conforenoe. Sir A. N10holgonn, Beitish Ambassador to Spain, in roporting to his government a conversation between himself and V1lla-Urrutia stated that the Cermen Charge d Nffaires had informed the span18h government that Villa-Urmatia's appointment "would not bo regarded in a friendly light by his Government."l. As for Italy. Germany belleved that in order to prevent a war she would urge France to accept Germany's terms. What is more, British public opinion was a littlo moro friendly toward Germany with the coming into power in Great Britain in December, 1905 of a Iiberal goverment. The Germans moant to work for the malntenance of the open door and economic equality for all, as well as, the complete Internationelizetion of Morocco (this would apply to any bank established also), but if there was a division of mandated territory for police reforms, Germany was going to see to 1 t that she recelved her share and one which would contain a port favorably located for later expansion in the interior.. The Cermans had one mor concern and that was that they should not be isolated at the Conferenoe; Bulow especially urged an avoldance of th1s danger. Cermany was practically 1solated in Europo as it was, but if she won at the Conference, the Entente 
Cordiale, at least, would be definitely weakened. If she lost, her 1solation would be publicly demonstrated. No one was more aware of the bad effect on the ingleFrench entente of French fallure at the Conference than Premler Rouvier who did his best to find out exactly how far England would $g \circ$ in support of France. Ho relled on Russian support because of the elliance with her and her dependence on France for a loan. He did not expect opposition from elther Austria-Fungary or Belgium. But Rouvier was not absolutely sure of Britain, for which reason $M$. Paul Cambon, French Ambassador to Great Britaln, was instructed to sound that government's attitude. S1r Edward Grey, the new forelgn secretary, avolded the issue unt1l some answer to the French Ambassador's point blank question had to be made. Grey reports his conversation with $M$. Cambon in a despatch to the British Ambassador to France, January 31, 1906 , by wh1ch time the Conference had already begun. He says:

"The French Ambassador asked me agein today whether France would be able to count on the assistance of England in the event of an attack upon her by Germany.

I sa1d that I had spoken on the subject to the Prime Minlster (Campbell-Bannerman) and discussed It w1th hIm, and that I had three observations to submit.

In the first plece, since the Ambassador had spoken to me good deal of progress had been made. 
Our military and naval uthoritios had been in communication with the French, and I assumed that all preparations were ready, so that, if a crisis arose, no time would have been lost for want of a forma 1 engagement.

In the secand place,..... I had taken an opportunity of expressing to count Metterrick (German Ambassador to Groat Britain) my personal opinion,..... that, In event of an attack upon France by Germany, arising out of our Yoroccan agreement, pablic feeling in England would be so strong that no British govermment could remain neutral.

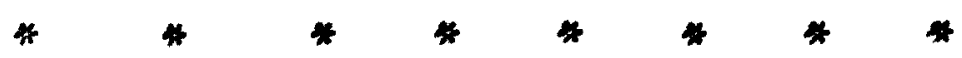

In the third place, I pointed out to M. Cambon that at present France's pollcy in Morocco,..... was absolutely free, that we did not question it, that we suggested no concessions or alterations in 1t, that we left France a fres hand and gave unreservedly our alplomatic support on which she could count, but that, should our promise extend beyond diplomatic support and should we take an engagement which might involve us in war, I was sure my colleagues would say that we must from that time be consulted with regard to France's policy in Morocco, and, If need be, be free to press upon the Frenoh government concessions or alterations of their policy which might seem to us desirable to avoid. I. 
The British government, as indicated in the above despatch, had already conceded the advisability of secret military and naval conversation between the two Powers, but through s1r Grey's adrolt handling of the question of aupport of Prance in case of war, England managed to

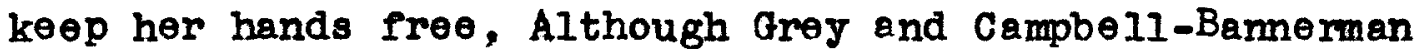
emphatically expressed their allogiance to the Entente Cordiale, Grey knev that if France lost at the Conference the prestige of the Entente would suffer, hence he declered that "our main object therefore mast be to he fp France carry her point at the Conference."I. Thus, he determined that Cermany should formally recognize France's preponderant position in Morocco.

Both the British and French urged spein to remain lojal during the conference. There was good reason for doing so, for, as the Spanish Primo Minister admitted, Germany had been making persistent attempts to detach Spain from France and England. When the Italian govermment was approached by Great Britain to press the former for her support, she replied that because of her position In regard to the Triple Alliance she could make no promises In attacking the priem of police at the conference, Great Britain and France agreed to a suggestion made by the Russien Minister at Tangier, that the police question be

$$
\begin{aligned}
& \text { I.Ib1d,, 168, No. } 200 . \\
& \text { 2.Ib1d., 167, No. } 208 .
\end{aligned}
$$


discussed solely from a practical polnt of view, with out reference to its political aspect. When it became simply a question of the protection and safety of foreigners in Morocco, it would appear quite logical to those acquainted with Morocco that the work could be best done by the French and the Spanish who were used to handling the natives there.1. Cermany would be held responsible for breaking up the conference if she rejected this plan. In the instructions given to the French delegates, French demands called for the commlssion to France and spain alone of the suppression of contraband trade and of policing, and the establishment of a bank in which France should have a superior position, and which should not only be under the French legal system but have a French president. Internationalization of the police was to be absolutely refused as should be also any proposal placing a minor power in control of the police. It might be mentioned with interest that the demands which France intended to make at the Conference were practically identical with the fallen Delcasse's a im in regard to Morocco.

\section{On January 16, 1906 the Conference of Algeciras} was formally opened with the Spanish Duke of Almodovar prosiding. The town of Algeciras marked the landing place of the Moors in Spain on three successful invasions, now, the scene of a meeting which promised to decide the 
fate of the1r Empire. Modern Algecires, dating from 1760 , is a qualnt town w1th narrow cobblestone streets, plaster bulldings with shutters, grill incesed windows, and grilled 1ron balconies. In preparation of the Conference, the whole town had been whitewashed, the paving repaired, and the grass removed from the streets. Sessions were held in the Town Hall which boasted red carpet on Its interior stalrcases and rows of flower pots down the steps descending to the pat1o. The delegates met in the largest apartment in the Town Hall and sat around a long T shaped counc1l table covered with green baize. From the celling of the room were suspended many electric light bulbs the brilliant glare of which was hardly softened by the shallow fluted shades above them. .

Algeciras was really a very poor cholce as a conference town. There were only two hotels. The newseper men were quartered at one and most of the delegates at the other, the Reina Criatina, a low-storled, bow-windowed structure under scotch management. It was situated on the promontory which divides the coulf from the stralts of Glbraltar, 80 that it faced the Rock of Gibraltar. Some of the delegates rented separate villas, as did the British delegation, but at exorbitant prices. Nicholson, head of

1.For description of Algeciras and the Town Hell see sydney Brooks, "The United States at Algeciras", Harpers meekly, 50:402; Henry C. Lodge, "The Monroe Doctrine and Horocco," Ibid. 332-3, Fortnightly Review, "The Algeciras Conference , 85; 9406\%; Harold Nicolson, Portrait of a Diplomatist, 126. 
the English delegation, and his three assistents paid a rental of 110 per day for 84 days.1.

The number in each delegation ranged from fourteen in the French to tro for those powers who attended the Conference almply because they were signators to the Madrid Convention. The Moroccan party, however, includIng elght regular delegates, numbered upwards of sixty persons, all of whom added a decidediy picturesque note to the assemblage of people in the town. They came in Moorish attire wearing white robes and red and white turbans.2. Furthermore, the Moroccan delegetes always rode to the meetings on muleback. The ir head was sid Mohamed Torres, an octogenarian, and a decendant of Spaniah Arabs who once had occupied southerm spain. In fact, the old man possessed the key of the house, which his ancestors had IIved at Cordova. He had a long white, spotless beard. He walked bent over an Ivory-topped stick, wrapped from head to toe in a white wool mantle.3. A slight, sinlling man with a waxed mustache, M. Révo1l, headed the French delegation. He was a subtle reasoner, but overcautious,

1. Fortnightly Review, "The Algeciras Conference",85:940. 2. outlook, "Conference of Algec1ras," 82:103.

3. Salvatore Cortes1, "From Pertsmouth to Algeciras", Independent, 60: 1152.

4. For a description of the other delegates seo N1colson, Portrait of a Diplomatist,126ff.,Anderson, Moroccan Cr1818, 349. 
obstinete, and mistrustful of Germany. Sir Atthur Nicholson, as mentioned above, was the leader of the British and probebly the most able person at the Conference. Although the blue-eyed little man had nothing In his perscol appearance to command regard, since his frasl person was twisted with rhoumatism and arthritis, jet he had a sense of control and his quiet work real.1y brought the Conference to a definite conclusion. Germeng sent as her leading representatives Herr von Radowitz, who was so old and feeble as to oount for pract1cal1y nothing, and count Tattenbach, whose unpleasant personelity harmed his country's cause. Nicholson described him a a rasping, disagreeable man, meither straight-foward nor truthful, whose blunt agiressiveness created a bad impression. 1 . our representatives were Mr. Wito, Ambas sador to Italy, and Mr. Cummeré, Minister to Morocco. The former was charming and conc1liatory, but not very well informed. Italy sent the seventy-six jear old v1scont1 venosta, white-ha1red and bewhiskered, one-time Porelen Minister under Cavour. Count Cassini, who was sociable but not very dependable, represented Russia. Count Welsersheimb was AustriaBungary's chief delegate, as was the Duke of Almodovar for spain. Besides the regular delegates there were about fifty joumalists.

1.B.D., III, 243, No. 268 . 
Formal sessions were held from ten to twelve o'clock in the morning, and were reserved for rat1fication of matters agreed upon unanimousiy in the committee of the whole, composed of all delegates sitting unofficially and engaging in free debater. Conference oomittee meetings were held from three to five o'clock in the efternoon. The drafting and translating committees, the latter made up of the delegation interpreters, met whenever convenient. The members of the translating committees had the hardest work of all to do, for they had the thankless task of translating Arabic into French and vice versa. The formal me日tingrere held at irregalar intervals, about tiree times a week, or whenever the President of the Conference was advised that instructions had been recelved sufficient to 1s sue a summons or when the drafting committee had some document ready to present for consideration. In a11, there were about thirty sittings of the conference. They were, however, interspersed with agonizing periods of delay because the Moroccan delegates were forever referring to their govermment, a procedure which required about two week'g time, since the Koroccans would make the trip across the Mediterranean to their country and

1. For organization of the Conference $8 \theta \theta$ Fortnightly Review, "The Algeciras Conference," 85; 941; Irrers on, Moroccan Cr1sis, 350. 
and back again. More important than the regular meetIngs of the Conference were the direct negotiations between the French and Cerman delegates, negotiations which became almost constant after January 25, 1900. 
Chapter III

THE PROBLEM OF THE STATE BANK 
Chapter III

The Problem of the state Bank

The Duke of Almodovar, President of the Conference, in the opening speech expressed the principles which were to govern the work of the nations there assembled. He declared that everyone desired "reforms based on the triple principle of the sovereignty of the Sultan, integrity of his ompire, and equality of treatment in matters comercial, that 18 the open door." He said It was not the intention of the Conference to devise a complete plan of reform for Morocco, but rather to "study together the means of applying measures which at present appear to be the most urgent and easiest to introduce."1. The Conference got busy at once on the problems which it could settle with the most facility. These included the survelilance and repression of contraband arms; Improvements in the collection of taxes and ways and means of creating new revenues; regulations concerning customs duties and the repression of fraud and of contraband; and a declaration relating to public services and public works.

When the above matters had been taken care of, the Conference was ready to turn to the two major problems, the establishment of a state bank and the organization of pollce in Morocco. The settlement of these two was 
very important, for 1t would not only determine the future of the Moroccan state but also greatly affect international politios on the Buropean stege. Discussions on the bank and police proceeded, for the most part, simultaneousiy or alternately, one being taken up when the wark on the other had struck a snag. The story of each of these problems, however, shall be discussed here separately. Although this method w11l not show so well the manner in which the chief delegates juggled the discussions to sult their om onds, It will have the greater advantage of giving a clearer, more connected account of the handling of each problem. In the consideration of both questions, the relationghip between France and Great Britain mast be constently borne in mind. It is well expressed in King Edward's words to M. Cambon just before the Conference: "Tell us what you wish on each point, and we will support you w1 thout restriction or reserves." ' 1 .

The problem of the state bank will be taken up first. The French, asal ming the initiative, presented to Count Tattenbach on January 29 their plan for a bank. There were six major articles concerning the establishment, management, and control of such an institution. They provided for

(1) A bank oubject to French 1 aw and the French judicial system;

I. Sidney Lee, King Edward VII, V.II, 361. 
(2) A division of capital as follows: France, 27\%; Spain, 23\%; Great Britain, 20\%; Germeny, 20\%; Italy, 10\%;

(3) An administrative counc1l of ten to be chosen according to nationality by the shareholders;

(4) A directory named by the councirs

(5) A comitter of discount in Tangler selected from resident shareholders and a committeo of examination to be chosen by future subscribers;

(6) The preferential right to make loans held by France to continue, but possible relinquishment in retum for an increase in the percentago of capital to be given France. 1 .

The French based their demends on their preponderant economic interests in Morocco, which they felt had to be recognized. From the French view point, it was a question of maintalning the open door without losing interests already acquired. To them "the open door (did) not signify that those who are in the house mat leave." 2 .

The Germans, not yet ready to make any concessions, objected to France's claim to preference for making loans. They also proposed the use of the Egyptian mixed codes and what was particularly ropugnant to the French -- the equal division of the capital among the Powers, a proposal which,

1. Anderson, Moroccan Cr1s1s,352, from G.P.,XXI, 128ff., No.6874.

2. Andre Tardleu, La Conference, D'Algeciras, I4lff. 
If accepted, would simply amount to the internationalization of the bank. Both governments became very busy trying to win the ot her Powers to their support. Germany was anxious for Italy, Austria, and the Unlted States to declare themselves in favor of her plan; she did not desire British mediation, for it might result In active English support of France.

For the time-being, horever, the question of the bank was allowed to ride while attention ras turned to the problem of the pollce. In the latter part of Febmary negotiations on the pollce reached a standstill. To prevent the dismuption of the Conference, the Germans returned to the bank questi on and on February 20th both France and Germany submitted the1r bank plans, revised sconewhat, to the comitter of the whole. Since it would only be confusing to describe each plan separately, article by article, we shall confine our attention to the for differences between the two proposals, the differences and the diplomacy connected with their adjustment constituting, after all, our chlor interest in FrancoCormen relations at the conference of Algeciras.

In the first place the two countries differed over the location of the central office of the bank, which dermeny thought should be at Tangier, while France insisted on Par1s, posstbly because French bankers would have a 
superior interest in the bank according to the French plan. In the second place, Germany desired that the statutes governing the bank should be drawn up by a Conse1l d'Administration composed of two delegates from each national group and ratified by a Conse1l de survelilance composed of the diplomatic representatives at Tangler. Also, she wished the bank to be subject to the Egyptian mixed codes. According to the French plan, the statutes were to be drawn up by a comittee chosen from the various subscribing groups and ratifled by the stockholders, the bank to be subject to the French low and the French judiclal system. A third major difference was in the supervision of the bank. The Germen plan called for supervision by the Conse1l de surve1llance, mentioned above, and management by the Conse1l d'Adminstration, aloo montioned above, under the guldance of a director chosen by the last mentioned body. The French, on the other hand, desired the bank to be directed by a Conse11 diAdministration composed of fifteen (15) members selected by the shareholders, each chosen from the nationality of the subscribing group. This body was to select the bank officers and determine their power. In addition, there was to be a high comalssioner chosen by the Moroccan government to watch over the bank for the Sultan. The fourth, and really the most important difference 
between the tro plens, concerned the division of capital. Germany Flatly demanded an equal division of the capital among the powers, as she had done from the flrst. The French plan would divide the capital into fifteen parta, eleven of which should be subscribed by financial groups In Germany, Great Britain, Austria, Belgium, Spain, the United States, Italy, Holland, Portugal, Russia, and Sweden With no power having more than one part; the remaining four perts would be given the French group of benks which had made the Horoccan loan in 1904. France was demanding for her banks the right of subscribing a greater share of the capital than her first plan called for; but sho did so to gain compensation for her present willingness to relinquish the right of preference for making loans to Morocco, a privilege to which Germany had objected atremausiy.

Gormany opposed the French plan on the ground that It would make the bank a French institution and not an international one. France returned $w 1$ th the argament that the German proposals completely ignored France's rights and superior interests in Morocco, that they created not an economical institution but political one, aimed at France. Furthermore, France held that Germany's plan was impracticable because diplomatic ropresentatives were not qualified to assume the responsibility in regard to the bank which Germany chose to give them. ${ }^{1}$. Because the plans

1. B.D.,III, 265f., No. 288 . 
were so conflicting, discussion of them was deferred unt1l France and cermany should negotiate further. By March 3 it appeared as if the conference was on the verge of fallure, for an impasse had been reached on the question of the police as well as that of the bank. The major opponents busied themselves, as before, in trying to win the lesser powers to their support. Their activit1es will be taken up in greater detall in connection with the more 1mportant problem of police.

The English, particularly Foreign Secretary Creg, were very pessimistic over the outlook of the Conference and were concerned lest France be held responsible for its dismuption. Sir Arthur Nicolson, therefore, and M. Révoll sought a means to prevent a break up of the Conference over the bank question. They decided to bring up the pollce question and push it through to some kind of conclusion, favorable to France it was hoped. Rupture of the Conference over the bonk would create a very bad impression on public opinion; for the bank question was not as readily understandable as the police question, and people would not comprehend why the financial diffl culties could not be settled farorably by both parties. The police question was accordingly taken up, but was once more dropped temporarily whenno agreement could be reached.

Finally, on March lith the Conferenoe turned again to the bank upon the proposal by N1colson, with the approval of Révo1l, that there should be chosen three censors 
(later, four) who should oversee the bank and submit their reports to a councll of adminstration of the bank. The German representatives accepted the proposal on condition that the censors be chosen by the respective governments from the personnel of the banks interested in the Moroccan state bank and on condition that the signetory Powers recelve coples of the censor's reponts, "as being the only way of asuring the international State character of the right of control, a point of view, In our (ther German) opinion, to be observed under all circumstances". I.

By this time, however, Cermany had given up her. demand for equal division of the capital but was willing to concede only three (3) shares as against the four (4) demanded by France. The varlous Powers urged Cermany to compvomise. In the meanwhile, the lustrians had brought forth their compromise proposal concerning the police. on March 23 Count $\pi_{0}$ lsersheimb informed $M$. Révoll in pr1vate conversation that if France would make some concessions, Germany might give up hor demand for notaral pollce at the port of casablanca. 2. The count's suggestion was a happy one, for R6roll ind1cated France's willingness to accept only three (3) shares in the benk.

$$
\begin{aligned}
& \text { 1.Q.D.D.,III, 245, XXI, No. } 272 \text {. } \\
& \text { 2.B.D., III, 3191., No. } 379 \text {. }
\end{aligned}
$$


The question of the degree of international control which should exist over the bank was not solved at this point; Cermany, in expected contrast to France, thought that the verious governments and the diplomatic corps at Tangier ought to have some authority over the censors. However, mediation triumphed again in the face of French refusal to give way, and on March 26, both Germany and France made concessions on the control of the bank.

At the last moment, France met w1th complications in the shape of Spain. According to the Franco-Spanish agreement, Spain would recelve her share from France later on. She now demanded it at once, but France refused, and spain had to content herself as best she could.

At last, the problem of the bank was settled, the decisions pertaining thereto being briefly sumarized, as follows:

(1) There were to be four (4) censors selected Wth the approval of their gevernments by the Banks of England, Gormany, France and Spain, and charged with the duty of supervising the administration of the bank. They were to make an annual report.

(2) There were to be a council of administration and a H1gh Comissioner appointed by the Moroccan Government. 
(3) The State Bank of Morocco was to have the exclusive privilege of issuing bank notes. It was to act as the state treasurer, recelving, for instance, the customs duties, and was to furnish the funds for the organization of the police and for public warks as well as to ke loans to the Government up to a million francs.

(4) The totel capital was to be fifteen (15) to twenty (20) milizon francs divided into fifteon (15) shares, three (3) going to France, and the remainder to be divided among the signatory powers. 
Chapter IV

THE PROBLEM OF THE POLICE 
Chapter IV

The Problem of the Pol1ce.

The question of the Moroccan pollce was by far the more important of the two major problems facing the conference. France at the very beginning was prepared to accept some degree of intermationalization in regard to the state bank, but she entertained no such ideas about the police. In fact, Révoll informed the American and Italian delegates that France would prefer the status quo to any police arrengement which might be inimical to her influence in Morocco.1. Confusion characterized German policy at the Conference as it had throughout the whole Moroccan affalr. For that matter, confusion had been the keynote of Berman forelgn policy in general since the Iron Chancellor had teken a back seat. An example of this instability was to be found in the many reports of varlous German pollce proposals which were current and which were well calculated to berilder the French. In this situation, Nicolson urged Révo1.1 to be erank and open and lay his proposals before the cermen delegates. Such a procedure was not in harmony with Révo1l's nature, but he finally agreod to accept Nicolson's advice. The plan which the French presented on February 3 provided that the Frenoh and Spanish together be given a mandate for the police. As a guaranter of commercial equality, 
there should be international agreement upon the form, extension, and control of the mandate.

In the meantime, the Germans had dram up three possible plans, outlines of which were dispatched to Vashington, January 20. The flrst provided $f a$ the organization of the police by the various powers in separate districts, each power to assume a mandate for a port on the Atlantic coast. Unity of policy was to be achiered by general agreement on such questions as those of arming and training. The second plan rould entrust the entire police organization to a small power, preferably Switzerland. According to the third plan the Sultan should organize his own police with the aid of volunteer officers chosen by the sultan himself or by three of the small porrers. the trenty-third Baron Sternburg explained the plans to secretary of state Root who, saying that he personally approved Number 3, promised to consult President Roosevelt about the matter. The American representative at Algeciras informed his government that the plans were not practicable. Both the French and English delegates rejected them on the same grounds.

On January 24 there appeared in siecle a solution suggested by a French writer, M. De Lanessan, which it w11l be seen followed closely the lines of cerman's third plan. Said M. De Lanessan: "There remains only one admissable

1. Anderson, Morocean Cr1s1s, 353; B.D.III, 235, No.256. 
solution; to charge the sultan with the pollcing of h1s empire while determining the means by which he should have control and whilo instituting an international control over the organization and employment of those means." Bulow seized upon this plan at once and urged President Roosevelt to sponsor 1t. The United States Gorernment was Informed by Cermany that Austria, Itely, and Russia approved this scheme. This was on the thirtieth. Nicolson rereported to his government, however, that Germany had int1mated to the spanish Forelgn Minister on the tronty-sixth the possibility of a combination for police, made up of France, Spain, Italy and Germany?. Harold Nicolson points out that cormany was also suggesting both at Madrid and in Italy that the police be entruated to spain alone.3 This he calle German's "smoke-cloud" pollcy.

Though sympathetic to the De Lanessan plan, the Italian, American, and Russian delegates expressed their approval of the French plan of Februery 3 as the most modorate and practicable. Tattenbach's efforts in private conversation with Nicolson on February 3 to get the latter to urge concessions on the part of France were a fallure. Radow1tz advised the Germen government to compromise, but Bulow was umiling. It looked as if the Conference was

\footnotetext{
1.Anderson, Moroccan Cris1s, 354, from G.P.,XX, 123ff., No.6968. 2.B.D., III, 239, No.262. 3 .N1colson, Portra1t of a D1plomatist, 133.
} 
going to break up Inasmach as France also refused to yield. Mr. Wite notes in a telegram to his government on February 5 his bellef that "France will allow the Conference to fall rather than recede from it (her position) ...." Austria even urged her ally to agreo to the French plan with modifications. Germany was still hopeful of United States mediation but recelved no definite reply from Washington to her advances. Count Witte wrote to his Germen friends advocating the necessity of a conc1liatory spirit on the part of cormany and pointing out the very apparent superior interest of France in Morocco.2. Finaliy, on February 13 Radoritz spoke directiy to M. Révoll submitting a new plan which the French delegate very reluctantly transmitted to his government. The new plan contained these provisions:

(1) The sultan should organize the police force to be established in certain specified localities and to be commended and organized by forelgn officers freely selected by him.

(2) The state bank should supply funds for the establishment of the police force. This provision caused no difficulty.

(3) The diplomatic body at Tangler should exercise control over the execution of the police organization.

1.A.L.P.Dennis, Adventures in American Diplomacy 1896-1906, 501. Hereafter this Work Dennis, American Diplomacy.

2.André Tardieu, Laconférence D'Algéc1res,246. 
(4) A superior foreign officer or inspectorgeneral should be selected from one of the minor Powers to inspect the police force and report to the diplomatic body at Tangler.

(5) The plan should be an experimental project to last from three to five yoars. ${ }^{1 .}$

If Germany expected to gain support for the above, she was again to be disappointed, since the important powers all more or less openiy expressed their disappooval. The Austrians once more pressed Germany to compromise, because the former country was suffering so with domestic troubles that she did not wish to be involved in an international confilct certaln to occur if the conference broke up with out a settlement. Germany replied with a show of bluster. On the same day that she presented her plan, Germany sent the following cryptic telegram to Rome, Washington, vienna, Iondon, and saint Petersburg:

"No reason for a further retreat is evident. The principle of sacrificing one's own interests merely because they block the way for another Power could lead to such serlous consequences that we consider a dismuption of the conference as the lesser evil."2.

I.B.D., III, 257, No. 287 .

2. Anderson, Moroccen Crisis, 359, from G.P., XXI,1591. and note, No. 7000 . 
In other words, Germany was serving notice on the powers to the effect that if they did not want the Conference to break up they had better persuade France to give in, for Germany would not. Cermeny at this time also complained of the ant1-German flavor of the French press, responsibility for which Rouvier emphaticaliy denied.

Germany's bullying attltude served merely to allenate the one power she had most depended upon with the exception of Austria, and that was the United States.. To Ambassador Jusserand's request oarly in February that Roosevelt intervene in favor of the French plan, the French government recelved a favorable reply. France could now be certain of British, American, and Russian support, a practicel guaranter of success.

But France did make an attempt to reconclie the German plans with her own demands. She did 80 at the instance of the Italian delegate, who, naturally, was most antious to prevent a fallure of the conference. In a memorandum Révoll informed Radoritz on February 16 that France would accept the Derman plan provided the Sultan chose French and spanish officers and that the question of the Inspectorceneral be left to the conference to decide?. The proposal was rejected. Then it was that the American Covernment stepped in.

1. Nicolson, Poptrait of a Diplomatist, 136. 
on February 19,1906, Secretary Root aubmitted to Ambassador sternburg an American plan. It consisted of four (4) main points:

(1) The Sultan should organize his own police force, the men and officers of which should be Moors.

(2) The proposed state bank should supply the money to maintain the police.

(3) Franch and Spanish officers should as sume the duties of instruction, discipline, pay and assistance in management and control. They should be appointed by the Sultan and should report annualiy to the Government of Morocco and to the Government of Italy, which latter Power should have the right of Inspection.

(4) France and Spain should guaranteo the open door 1 . Although the French press was host1lo to the American proposals, the French government g geed to accept them.

As for Germany, Bulow at first refused completely to accept the plan, but on second thought, apparently, the German Government decided to expross 1ts objections, which nere embodied in a memorandum from Stemburg to Roosevelt on Pebruary 22. Stermburg stated that the Fmperor agreod on all points but the third. The Emperor considered that point three was practically the same as the French proposal which required that the sultan choose only Spanish and French

\section{Quoted in Bishop, RooseveI, I, $489 \mathrm{ff}$.}


officers. The Emperor said that he objected to an arrangement of this kind because it "would place the pollce forces ent1rely in to their (the French and spansh) hands, and the pollce organization would be tantamount to a FrenchSpantsh double mandate and mean a monoply of these two countries, which would heavily curtall the political, and economic positions of the other nations." 1 . Germany then suggested that the sultan should (1) choose the off1cors from among the nationa participating in the state bank, and (2) select them from at lesst four different nationalities, this last to allay French fear that the Sultan might choose only Germans. Furthermore, it was suggested that France might be allowed complete control of police in Tangler, or some other port, by way of recognizIng her special rights in Morocco. Officers of varlous nations should cooperate in all other ports.2. Roosevelt and Root refused to mediate on the basis thus outined by Germany, since they knew quite well that France would not accept such offers.

The Conference had now reached a crisis. It was evident enough if the Conference broke up France would not be considered responsible, but that fact, however, would be small comfort in the face of a terrible war. The German Ambassador to Russia expressed to the Russian Forelgn Minister his difficulty in understanding his government's ob-

$$
\begin{aligned}
& \text { 1. Ib1d., } 491 f ., \\
& \text { 2. Ibid., } 492 .
\end{aligned}
$$


stinate defense of a right, "wh1ch all other Powers, in view of the practical solution offered by the French, are ready to give up."'I. The English were very pessimistic, Grey suggested to Germany that if the Moroccan affalr was settled he would do his best to bring about an Anglo-Cerman rapprochement, so greatly desired by Germany because of her growing 1solation on the continent. The Duke of Almodovar even submitted to the French and British representatives pollce proposal to prevent the Conference from falling. The plan, which provided for forelgn instructors at only two ports, France and Spain to have one each, was considered simply impossible by England and France; but they heartily thanked spain for her loyalty. Throughout this period Russia also was active in efforts to find a way out of the dilemma. Lansdorff urged the United States to intervene at Berlin and instructed Russian Ambassador to Sermany to leave no doubt in Prince Bulow's mind that if Germany broke up the Conference, Russia would regard her as the aggressor.

The British and French delegates consulted one another in regard to their procedure in view of a possible rupture of the Conference. They agreed that a rupture should not occur over the bank question; therefore, a consideration of 1 t at this juncture must be avolded

1.Anderson, Morocean Crisis, 367 from G.P., XXI, zilf.., No. 7037 . 2.B.D., III, 279, No. 320 . 
for the reasons mentioned in connection with the discussion of the problem of the bank. France's conclilatory spirit and moderation showed up best on the police question. In the second place the two Powers determined that responsibility for a rupture should not fall on either of them.

on February 23 the Austrian Emperor, Francis Joseph, actualiy intervened to the extent of requesting the cerman Ambassador to Austria to urge moderation on the pert of his government. The Emperor feared that in case of a vote at the Conference, Cermeny and Austria rould be 1solated. He feared also that the ties between Russia and the two members of the Entente Cordlale would grow closer. His mediation, like that of the other powers, met with little apparent success?. An example of the instability of German policy is to be found in the fact that Holstein now tried to open direct negotiations w1 th France. Premier Rouvier refused to consider such a procedure. 3 .

At length, when some sort of action became bsolutely Imperative, the Russian Forelon Minister proposed thet a vote of the powers be taken on the police question. The suggestion was not wholly acceptable to Róvoll and Nicolson because, as they very reasonable argued, the delegates of the 1088 interested powers, like the United States, Italy, Holland, Belglum, and sweden would probably hesitate to vote

$$
\begin{aligned}
& \text { 1.Anderson, Moroccan Cr1s1s, 374,fr.O.P.XXI, 2135,N0.7039. } \\
& \text { 2.B.D.,III,279. No.320. } \\
& \text { 3. Anaré Tardie, Laconférence D'Algroiras, 24lff. }
\end{aligned}
$$


and the fact that the Conference preferred the French police proposal would not be made plain to Germany. If Germany should rema in obdurant in the face of an unquestioned support of France by the Conference, she would then have to accept the blame for the Conference's fallure. ${ }^{1}$

March 3 marked the turning point in the Conference, for, on that day came the opportunity for which France and England were walting. The Italian delegate, M. Vicont1 Venosta, and Radowitz proposed to suspend the Conference while the experts were conferring on the draft articles on the bank question. Here was a chance to bring the police quetion under discussion again, and at the same time force vote in which all the delegates would be likely to take part. N1colson, therefore, moved thet the problem of the police be taken up while the experts were at work on the bank. A vote was taken. There were ten (10) votes in favor, three (3) opposed, the latter being cast by Morocco, Germany, and Austria-Hungary. Thus was German 1solation at the Conference glaringly revealed by vote on a mere point of procedure. Even Italy had openly sided against her ally. 2 .

After what had just transpired, Tattenbach was ready to concede that his government was too obstinate. 3 . But what is of more importance is Bulow's recognition that a

$$
\begin{aligned}
& \text { I.B.D.,III, } 274 f f ., \text { Nos. } 312 f \text {. } \\
& \text { 2.Anderson, Moroccan Cris1s, 375, fr.G.P.XXI,204f., } \\
& \text { No.7032, } 233 \overline{1 .,} \text { No. } 1051 \text {. } \\
& \text { 3. André Tardieu, LaConférence D'Algéc1ras, } 291
\end{aligned}
$$


declded change of policy on the part of Germany was needed. He took away the control of the Moroccan affair from Holstein and assumed personal charge of 1t. From this point on, Germany slowly retreated, salvaging as best she could the remants of her prestige.

Austria had submitted a plan to Germeny on the twenty-sixth of February which Bulow now seized upon as a means of preventing the break up of the Conference. Briefly, the plan provided as follows:

(1) The organization of police in Tangler, Saffi, Rabat, and Tetouan to be entrusted to France.

(2) The organization of police in Mogador, Darache, and Mazagan to be entrusted to Spain.

(3) In Casablanca, the organization of the police to be under the cormand of a Swiss or vutch officer who should be inspector over al I the police.

(4) The inepector to report to the diplomatic corps at Tangler, which should have general control over the reorganization of the police.1. Bulow accepted it on March 6 with the proviso that the comander at Casablanca choose his officers from other nationalities than French and Spanish. It will be seen that cormany was now wlling that officers of nationalities

1.Anders on, Moroccan Cris1s, 377, from G. P.,XXI,

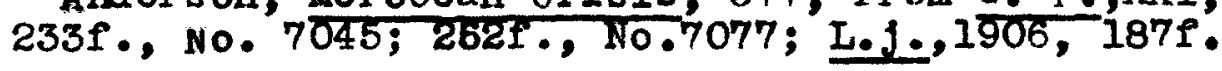


other than French or Spanish should be present at only one port.

on the e1gth, both the Austrian project and the French plan of February 16 were presented to the Conference. On the tenth, Count Radoritz moved that both of them be referred to a drafting committee. He said:

"It seems to me that accord ought to be reached on the basis of the two projects.... That of the French delegation certainly contains proposals which deserve the most serious examination. They ought to complete those of the Austro-Hungarian project."l.

It must be admitted that Radowitz's suggestion was an intelligent one. Sir EdwardGrey was very much pleased with the Austrian proposal. He wrote to Nicolson saying that since Cermany had conceded the substance,...." It would be a great pity, if France sacrificed the substance to the shadow." 2 . Nicolson was considerably disgusted when France refused to accopt. However, inasmuch as the British had promised France their complete support, N1colson continued to champion the French cause. But in conversation with Radowitz, he was told that Cermany would yield no more. St1ll, France remainded adamant.

1.Ib1d., 379, quoting from G.P.,XXI, 270, No.7085; 2180 B.D., III, 292f., No. $33 \%$.

2.B.D., III, 292, No. 335 . 
At this inopportune moment the French Governement foll, causing painful delay until a new one should be formed giving Révoll the right to proceed with the negotiations. Before his fall, Premier Rouvier had suggested throe (3) modificationg in the Austrian plan:

(1) The police instructors at Casablance should be French or spantsh.

(2) France and spein should determine the distribution of the ports between them.

(3) The Inspector-ceneral should report to the Sultan and not to the Diplomatic body at Tangler. The French also preferred a Dane as Inspector-General in place of a Dutchman, whom they feared might be under German influence.1. In addition, they demanded that the Inspector-General have inspection duties only. Although Venosta, White and Nicolson asked the German delegates to give way, the latter delcared that Germany postlively would not surrender her demand that the Inspector-General also be an instructor at one of the ports.

on the ninth of March President Roosevelt reminded the Kalser of his promise of June 28, 1905 to back up any decision which he (Roosevelt) should approve 2 . Roosevelt thought that Germany should accept completely the American plan of February 19. But Germany stuck to the Austrian plan and urged Roosevelt to support 1t. The President proved to be very much opposed to $1 t$, however, arguing

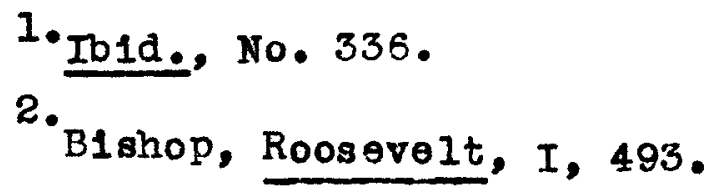


that a division of the ports among the powers provided for a potential partition of the territory. He sald: "The Immediate effect can only be the creation of three separate spheres of influence,..... And the nations to whom these spheres are assigned may be expected in the ordinary course of events to enter into complete control:l. The situation thus far was ably summed up by Nicolson in a despatch to Grey dated March 13, 1906.2. It appeared that Rovoll and his government thought that cermany would yield further, although Nicolson had his doubts. Germany was determined on some form of internationalization of the police, which she hoped to achleve through her demand that a third power be in charge of the pollce at one port. France, on the other hand would not accept internationalism in any form. If, through the inability of France and Germeny to agree, the conference were to fail, in the opintion of the majority of the Conference, the respons1bility would now fall on France. Nicolson felt that if France wald only yield on the point at 1ssue, for Instance, be willing to accept Swiss control at Casablanca, she might obtain her way in regard to the disputed questions connected with the state bank.

When the new French Government came Into power, the

$$
\begin{aligned}
& \text { 1. Ib1d., } 498 . \\
& \text { 2.B.D., III, 301., No. } 345 \text {. }
\end{aligned}
$$


new Foreign Minister, M. Bourgeols, amazed the powers by boldly renewing Révoll's instructions refusing compromise on the pollce. Some of the nations that had hitherto stood by France now expressed their disapproval. It was even feared in France that England might refuse her support. Great Britain, however unsympathetic she was with France's rather reckless behavior at this point, nevertheless remained faithful. At it turned out, French audacity was entirely successful. Austria began to seek some new ray out of the deadlock which should make it possible for Germany to accept the French view in regard to Casablanca. A possible way out might be for Germany to give way on Casablanca in return for some compensation on the bank question. However, before Austrian mediation took shape, the Un1ted states intervened again in favor of France. Roosevelt proposed that French and Spanish officers in about equal numbers should cooperete in each of the ports under the supervision of a general inspector from another nation. All along Roosevelt had disapproved of any arrangement which might tend toward the partition of Morocco. He had become convinced that this was Germany's aim. He informed Sternburg if Germany continued to reject American proposals and if the conference failed, he would publish the entire correspondence; otherwise, in a public address, he would give Germany full credit for what was done.1. On March 19 Germany accepted the plan and Roosevelt was delighted. 
Dennis contributes the sudden ylelding of Cormany to three (3) things:

(1) The very real desire on the part of the Kalser and Bulow to avold an European war.

(2) Roosevelt's throst to publish all the correspondence pertalning to the Conference.

(3) Germany appreciation of the fact that public opinion in the rorld and especially in America was hostile to German $y .1$.

But the story did not end with German acceptance of the American plan. When it was presented to France, she rejected 1t; likewise spein, for both nations opposed the idea of mixed police, except if necossary, in Tangler and Casablanca. Great Britain naturally supported the FrancoSpanish view. Nicolson expressed his fear that the United States' proposal was not practicable?. In the face of such opposition, the United States Government did not insist on the adoption of its plan.3.

Thus was the revised Austrian project, which was pending, rendered important once again. According to 1t, France and Spain were to be entrusted with the policing of all elght ports; Germany's compensation for giving way on Casablanca was to take the form of a substantial lessening In France's demands in respect to the division of the bank

$$
\begin{aligned}
& \text { 1.Dennis, American Diplomacy, } 505 \text {. } \\
& \text { 2. B.D.,III, 313, N08. } 360,367 . \\
& \text { 3. Ib1d., 320f., No. } 380 .
\end{aligned}
$$


capital. 1. As matters stood, Germany gave up her demand for a neutral police at Casablanca in return for which France agreed to limit her shares in the bank to three. The degree of international control which should exIst over the police still constituted a problem. Cermeny Insisted that the Inspector be made responsible to the diplomatic corps at Tangier, which should also exercise general supervision over the police; while France, supported by Great Britain and Spain, believed that the diplomatic corps should be excluded from participation in the matter. France desired that the settlement of the foregoing question and of other detalis be left for determinetion later by France and Spain together with the Sultan. Germany wanted the Conference to divide the ports between France and spain. Germany had made the great concession, yet France continued to hold out despite the fact that the delegates, who were anxious to conclude the Conference, believed in general that rrance should make a concession in the matter of the inspector's responsibility.

Mediation, however, began again. In the end, Germany agreed to a division of the ports by France and Spain with the approval of the conference. Both powers made concession on the question of bank control. A formula regarding the responsiblilty of the inspector was worked out by the delegates of France, England, Spain, Russia, and Italy meeting

$$
\text { 1. Ib1d.,317, No. } 379
$$


in consultation at Révoli's suggestion. The formula was submitted by $M r$. White to the German delegates who accepted it on March 27 .

At the last moment, as in the case of the bank question, Spain complicated matters between her and France by asking for Tangler to which request France would not consent, offerIng instoad the proposal that French and Spanish offlcers should jointly police Casablanca and Tangier. Spain had made her demand on the basis of the fact that, according to the Pranco-Span1sh agreement of 1904, only flve ports were to be pollced, but the Conference had dealt with all elght, France desiring the extra three for herself. Although spain at first refused the French decision, she finaliy accepted it on March 31. In addition, 1t was decided that there should be spanish officers in Tetouan and Larache with French officers at the four remaining ports. Thus all elght ports were accounted for. The division agreod upon by France and Spain was approved by the Conferance, which also accepted the following terms in regard to the police:

(1) They should funcation for five (5) years.

(2) They should be inspected at least once a year by a Swiss inspector stationed at Tangler who would be required to report to the Sultan.

(3) The inspector should also make special reports to the dean of the diplomatic corps upon the request of that body.1.

1.Ib1d.,326f., No. 386 . 
It will be seon that Germany's final concesslons were that the Inspector-General should be an inspector only, with no detachment of his own, that he only report to the diplomatic corps and not be responsible to it, and that Casablanca should not be pollced by a thind Power.

The last draft was hastily drawn up and included a resolution pertaining to slavery in Morocco, which Nicolson had presented and to which the Moroccans uselessiy objected on the ground that the question of slavery had not been on the agenda. The delegates appended their signatures to the Act of Algeciras on April 2, the Conference formally concluding on April 7. The United States Senate ratified the Act in Decomber 1906, but attached a protocal declaring that the Unfted States would not assume responsibility for the enforcement of the provisions of the Act.

It is interesting to note that on April 12, 1906 Roosevelt, upon addressing a group of German war veterans, congratulated the German people and the German Empire upon the work accomplished by the Algeciras Conference.1. He had kopt his promise.

1.Bishop, Roosevelt, I., $501 \mathrm{f}$. 
Chapter V

C O N C LUS I ON. 


\author{
Chapter V \\ C O N C L U S I O N.
}

The Conference of Algeciras was a make-shift; it solved nothing permanently. Although the conclusion of the Conference relaxed the tension in Europe, the reforms agreed upon were far from adequate to the needs of the unfortunate Moroccan state. The right to police elght ports was not sufficlent to quell the general diaturbances in the country, and yet enough to embroil the French and Spanish in clashes with the nat1ves. In fact, Morocco was weakened rather than strengthened by the Conference. The mass of the people were hostile to reform and turned more than ever to the rebel chieftan Rasoull and to the Pretender for leadership. Those few who, really hoping for reform, had belleved in the powers' empty guarantees of Moroccan Independence and integrity, and who had placed their falth in Germany, were keenly disappointed. They had expected that France would be properly trounced at the Conference. Instead, the powers had supported her. As one Moor has sald "the Moors expected the Conference to study the industries of Morocco, the conditions surrounding the people, or the cause of the rebelilions in the interior in order to cure them."1. It is not necessary to point out that the Conforence did nothing of the sort. Morocco" (North American Review, Nov 16, 1906) 1042 . 
The same writer has emphasized the fact that reform in Morocco should not be on Christian but on Mohammedan 11nes. He predicted that a police force 1ike that called for by the Conference would be impossible in Morocco as long as the Morrocen mental attitude was such that the Moroccans felt no need of one. Furthermore, the bank to be set up would not be of much service to the natives, for not only did they not understand the principles underlying the banking system, but their rel1gion forbade them to deposit money in banks. Of course, this particular Moor was quite well aware of the fact that the reforms instigated by the Algeciras Conference were designed mainly for the benefit of foreigners in Morocco. opinion at the Sultan's court was divided on the question of acceptance of the decisions of the Conference. The sultan delayed signing unt1l Jun 18 when he did so with reservations.

In the final analysis, the Conference of Algeciras was primarily an European affair. As the Italian correspondent of the Independent sa1d on May 17, 1906, the delegates really met to decide whether there should bo a paremount power in Europe and which power it shoula be. "Ancient hatred between France and Germany was coming to an is sue, complicated by the racial and commercial antagonism.between Germany and England." I. The meeting of the

\section{S.Cortes1, "From Portsmouth to Algec1ras".,} (Independent, May 17,1906, ) 1150. 
diplomats rendered the situation actually dangerous.

Delcassé made the serlous mistake of not squaring French spirations in Morocco with German desires before he sent his Mission of Reform to Fez. Germeny considered that her prestige had been impeired, and the Conference seomed to offer her a way to regain 1t. She attempted also, through the Conference, to obtain some material interests in Horocco and to overthrow the prevalling balance of power In Europe. She almed the destruction of the Entente Cordiale as well as that of the Dual Alliance, if possible, or at least, modification of the latter. But her attempt to 1solate France was complete fallure. She only succeeded in strengthening the very alignments she sought to destroy, whereas the Triple Alliance was visibly weakened. Through the Conference she had merely kept her promise to the sultan to do what she could to preserve his soverelgnty and had kept the way open for the future. On the other hand, Germon lost the confidence of Europe and what was more important to her, the confidence of the Onited states. She would have continued to enjoy the American Government's support, which she possessed when President Roosevelt helped her to bring about the Conference, if the United states had not finaliy realized that Germany was champloning the cause of Morocco not for Morocco, not for the world, but for Germany. "Wo (Roosevelt and Root) became convinced that Germany was aiming in effect at the 
partition of Morocco which was the very reverse of what Bhe was claiming to desire."l. If Germany's position had been a sincere one, she would have deserved the credit of the world. After the Conference, the resignation of Holstein from the foreign office was indicative of a change of policy on the part of cermany. There was nothing for Germany to do but keep quiet or work for her much desired Anglo-German Alliance, which she proceeded to do. What was the outcome of the Conference for France? To be sure, she did not make Morocco practically a French protectorate as she had hoped, but she did emerge from the Conference with intermational acknowledgment of her special territorial, adminstrative, and financial interests there. To her, then, went the fruits of victory and to Germany the empty platter, although both Powerg declared themselves to be satisfied with the results of the Conference. There was one other very important benefit which France derived from the Conference. The Entente Cordiale had weathered the storm; it came out "a lasting, dynamic combination for checking Germany." 2 .

After all is sald and done, the thing to be remembered about the Conference of Algeciras is that it was not a single peinful incident, but only one of many episodes, each contributing its share of combustibles, and onding at last in the bloody conflagration which engulfed the world in 1914.

$$
\begin{aligned}
& \text { l.Bishop, Roosevelt, I, } 489 . \\
& \text { 2.Anderson, Moroccen Cr1s1s, } 402 \text {. }
\end{aligned}
$$


Government Documents.

1. Dugdale, E. T.S., editor, Cerman Diplomat1c Documents, III. Harper and Brothers, NeW York and London, 1980.

2. Fore1gn Relations of the Onited States, 59 Cong., 1 sess., H. DOC., 1, Serial No. 4941, Covernment Printing off1ce, Washington, 1906.

3. Gooch, George P. and Harold Temperley, editors, British Documents on the Origins of the War, III, 1898-1914. H. M. Stationery Ofr1ce, London, 1928.

\section{Blographies and Memolrs.}

4. Bishop, Joseph B., Theodore Roosevelt and His Times, I. Charles Scribner's Sons, New York 1820.

5. Grey, Edward, V1scount Fallodon, Twenty-Five Years 18921916, I. Frederick A. Stokes Company, New York, 1925.

6. Le日, Sir Sidney, King Edward VII, II. Macmilian and Company, London, 192\%.

7. N1colson, Herold, Portra1t of a Diplomatist. Houghton, Miffin Company, Boston 1930.

8. WIIhelm II, The Kaiser's Memolrs. Harper and Brothers, New York, 1922.

\section{Genera 1 Works.}

9. Brandenburg, Erich, From B1 smarck to the World War; A History of German Forelgn Policy 1870-1914. oxford University Press, London, 192\%.

10. Dennis, Alfred L. P., Adventures in American Diplomacy, 1896-1906. Dutton and Company, New York, 1928.

11. Gooch, Goorge P., H1story of Modern Europe, Henry Holt and Company, New York, 1922.

12. Hale, Oron James, Germany and the Diplomatic Revolution; A Study in DIplomecy and the Press. UnIversity Press, PhIladelphia, IgsI. 
13. Sulmitt, Bernadotte E., England and Germany, 17401914. Princeton university Press, Princeton, 1818.

14. Ward Sir A. W. and G. P. Gooch, The Cambridge History of British Forelan Pollcy, III. Macmilian and Company, Now York Ig23.

Spec1al Works.

15. Anderson, Eugene N., The First Moroccan Cris1s 1904-1906. University of Chicago, Chicago, 1930.

16. Tardieu, Andre, LaConference D'Algeciras: Histoire Díplomatique de lacrise larocaine (I5 Janvier TAvrII 1906. FeIIX Olcan, Paris, 1909.

Per1odicals.

17. Brooks, Sidney, "The United States at Algeciras", Harper's We elely, March 24, 1906: 50.

18. Cortes1, Salvatore, "From Portsmouth to Algeciras", Independent, May 17, 1906: 60.

19. Dilion, F. J." "Foreign Affairs", Contemporary Review, March 1960; 89; May 1906; 89.

20. Fortnightly Review, "The Algeciras Conference", May 1906: 85.

21. Harper's Feekly, "The United States and the Moroccan Conferencen, January 27, 1906: 50.

22. Independent, "How He Got. Into It", January 11,1906: 60.

23. Karam, Asaad Kalarji, "The Moroccan Question as Seen from Ulocco", North American Revier, November 16, 1906: 183 .

24. I1ving Age, "The Outc ome of Algeciras", Apr11 28,1906-249.

25. Lodge, Henry Cabot, "The Monroe Doctrine and Morocco", Harper's Weekly, March 10, 1906: 50 .

26. Nat1on, "The Moroccan Settlement", April 5, 1906: 82.

27. Outlook, "The Algeciras Conference", January 20, 1906: 82; Apr11 7, 1906: 82.

28. Review of Reviews, "The Iight That Europe Saw at Algeciras", based on an article in the Deutcho Revue (Borlin) May $1906 ; 33$. 